(2) norden 



\section{Håndtering av avfall ombord på fiskebåter og mindre fartøyer}


Håndtering av avfall ombord på fiskebåter og mindre fartøyer

TemaNord 2006:502

(C) Nordisk Ministerråd, København 2005

ISBN 92-893-1265-3

Trykt på miljøvennlig papir som oppfyller kravene i den nordiske miljøsvanemerkeordning. Publikasjonen kan bestilles på www.norden.org/order. Flere publikasjoner på www.norden.org/publikationer

Printed in Denmark

Nordisk Ministerråd

Store Strandstræde 18

1255 Copenhagen $\mathrm{K}$

Telefon (+45) 33960200

Fax (+45) 33960202

\section{Nordisk Råd}

Store Strandstræde 18

1255 Copenhagen $\mathrm{K}$

Telefon (+45) 33960400

Fax (+45) 33111870

www.norden.org

\section{Det nordiske miljøsamarbeidet}

Det nordiske miljøhandlingsprogrammet 2005-2008 utgjør rammen rundt de nordiske landenes miljøsamarbeid, både innenfor Norden og i forhold til nærområdene, Arktis, EU og øvrige internasjonale fora. Programmet legger opp til resultater som sikrer Nordens posisjon som foregangsregion på miljøområdet. En overordnet målsetting er blant annet å skape levekår som gir bedre helse for befolkningen i Norden.

\section{Det nordiske samarbeidet}

Det nordiske samarbeidet er et av de eldste og mest omfattende regionale samarbeider i verden. Det omfatter Danmark, Finland, Island, Norge og Sverige samt Færøyene, Grønland og Åland. Samarbeidet styrker samhørigheten mellom de nordiske land med respekt for de nasjonale forskjeller og likheter. Det øker mulighetene for å hevde Nordens interesser i omverdenen og fremme det gode naboskap.

Samarbeidet ble formalisert i 1952 med Nordisk Råds opprettelse som forum for parlamentarikerne og regjeringene i de nordiske land. I 1962 underskrev de nordiske land Helsingforsavtalen, som siden har vært den grunnleggende rammen for det nordiske samarbeidet. I 1971 ble Nordisk Ministerråd opprettet som det formelle forum til å ivareta samarbeidet mellom de nordiske regjeringer og den politiske ledelsen i de selvstyrende områder, Færøyene, Grønland og Åland. 


\section{Innhold}

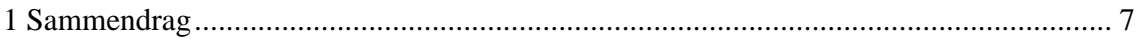

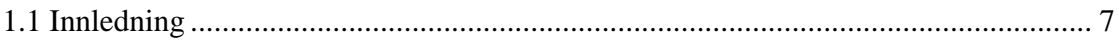

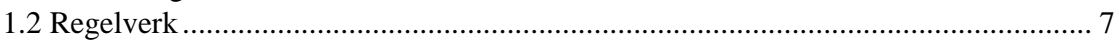

1.3 Avfallshåndtering og avfallsteknologier ................................................................. 8

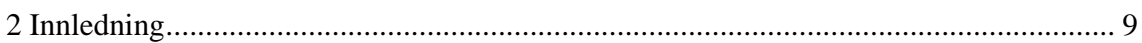

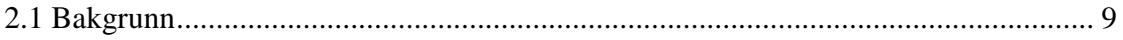

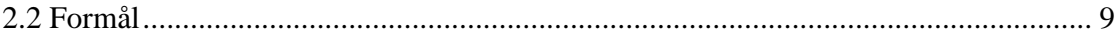

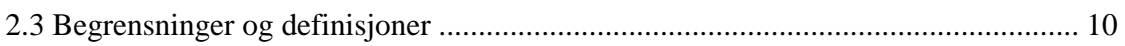

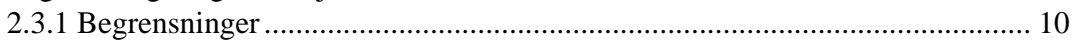

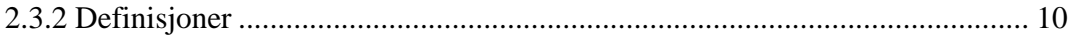

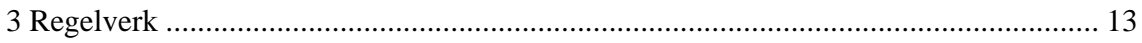

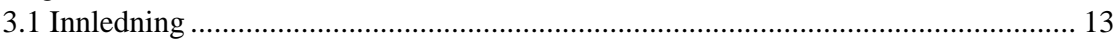

3.2 Olje 14

3.2.1 Utslipp av olje eller oljeholdig lensevann ................................................. 14

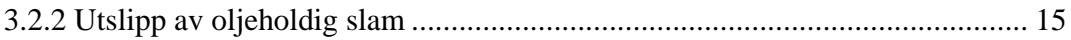

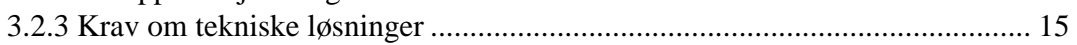

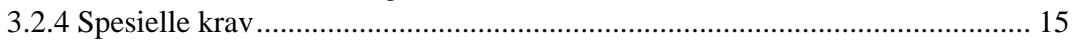

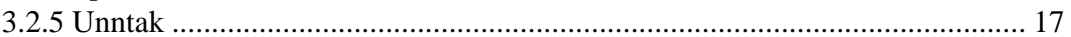

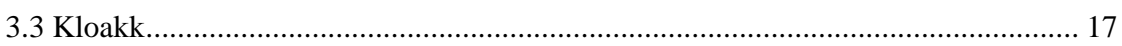

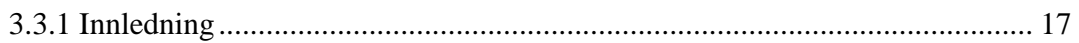

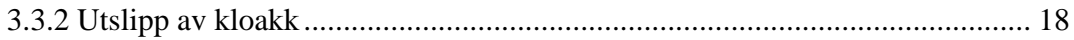

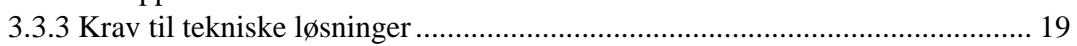

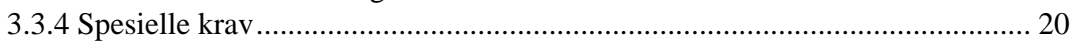

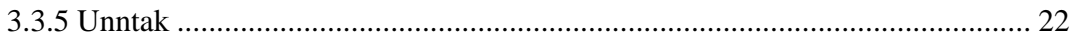

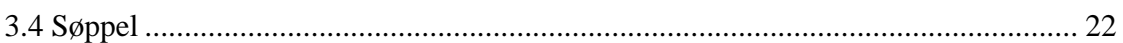

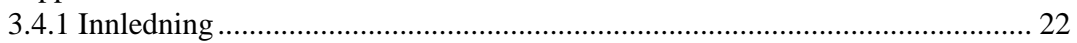

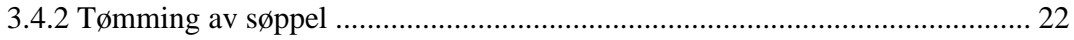

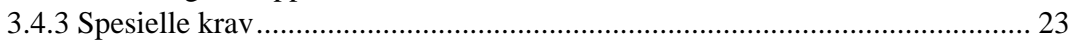

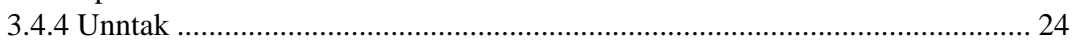

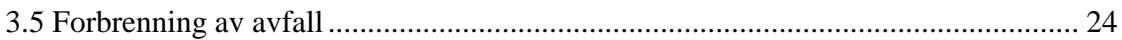

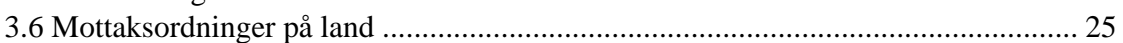

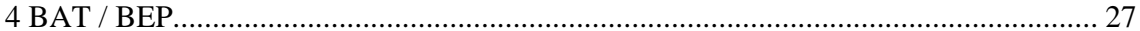

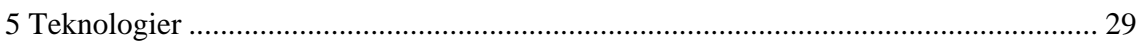

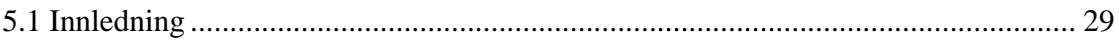

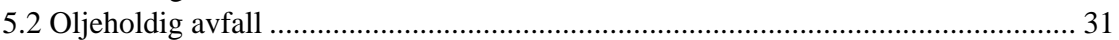

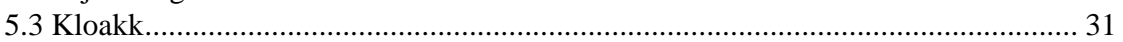

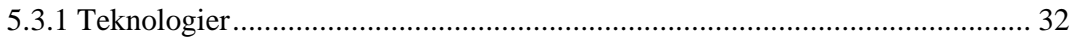

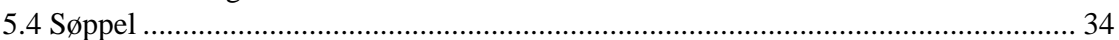

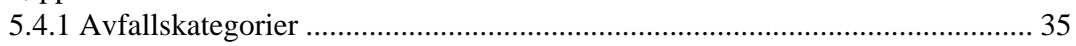

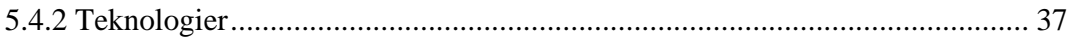

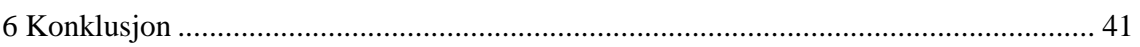

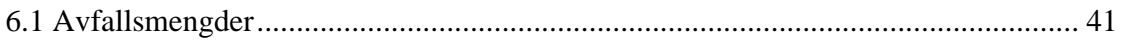

6.2 Håndtering av oljeavfall i fiskefartøyer og mindre båter......................................... 42

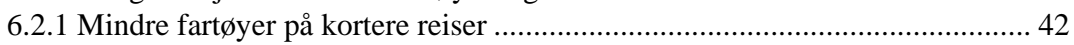

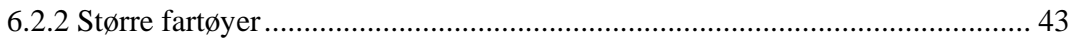

6.3 Håndtering av kloakk i fiskefartøyer og mindre fartøyer ....................................... 43 


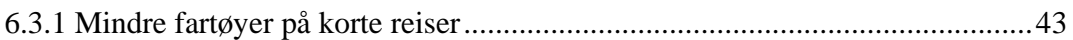

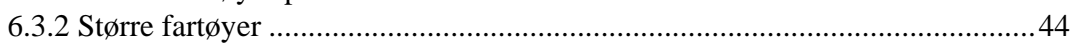

6.4 Håndtering av søppel i fiskefartøyer og mindre fartøyer ......................................... 44

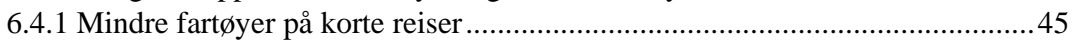

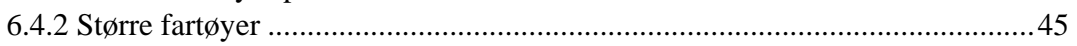

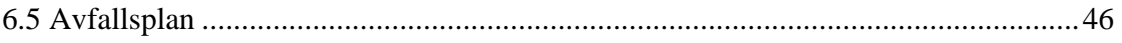

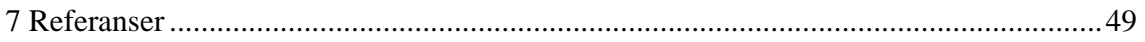




\section{Sammendrag}

\subsection{Innledning}

Denne rapporten gir innsikt i gjeldende regelverk samt en oversikt over hjelpemidler og teknologier som finnes og som kan bidra til å sikre effektiv håndtering av avfall fra fiskefartøyer og mindre fartøyer. De avfallskategoriene som er diskutert inkluderer hovedgruppene olje, kloakk og søppel. Definisjonene som er benyttet i dette arbeidet refererer seg til de definisjonene som er brukt i International Maritime Organization (IMO) sin internasjonale konvensjon om hindring av forurensning fra skip 1973 med tilleggsprotokoll av 1978, MARPOL 73/78.

Formålet med arbeidet er å formidle informasjon og kunnskap om sikker og effektiv avfallshåndtering fra denne fartøykategorien i henhold til gjeldende regelverk på dette området. Arbeidet forholder seg imidlertid også til prinsippene i relasjon til beste tilgjengelige teknologier (Best Available Techniques, BAT), beste miljøpraksis (Best Environmental Practice, BEP) så vel som til særlige bestemmelser som gjelder i aktuelle nordeuropeiske farvann.

Rapporten identifiserer retningslinjer for avfallshåndtering ombord. Det være seg teknologier, systemer så vel som rutiner og rapportering. Disse er så presentert i form av en informasjonspublikasjon. Målgruppen for informasjonsmaterialet er redere, besetning så vel som verft. Informasjonspublikasjonen er dette prosjektets sluttprodukt.

\subsection{Regelverk}

Utslipp av avfall fra skip er regulert gjennom MARPOL 73/78. Regelverket har som formål å unngå at skipsgenerert forurensning oppstår i det marine miljø. Regelverket i MARPOL 73/78 er å anse som minimumskrav, noe som betyr at de ulike landene eller regionene kan sette strengere krav om ønskelig. Dette er også gjort i flere områder. Regelverk nedfelt i OSPAR-konvensjonen (Oslo-Paris Convention), EU og Helsinki-konvensjonen (HELCOM) gir strengere krav på noen områder og vil bl.a. ha betydning når det gjelder håndtering av avfall ombord på skip i det nordeuropeiske farvann. 


\subsection{Avfallshåndtering og avfallsteknologier}

Ansvarlig miljøsikker håndtering av avfall begynner oftest med etablering og implementering av gode og effektive rutiner. Gode og effektive rutiner setter krav til tilrettelegging så vel som til etterlevelse. Rutinene bør derfor beskrives i en enkel og lett tilgjengelig avfallsplan, helst oppslått ombord der avfall genereres.

Forutsetninger for god avfallshåndtering fra fiskefartøyer og mindre fartøyer hviler på følgende enkle elementene.

- Bevisstgjøring og opplæring - motivasjon

- System - implementering av rutiner og prosesser

- Måling - overvåkning og verifikasjon

Etableringen av disse starter enklest ved å etablere definerte målsetninger for driften. En slik målsetning vil sette krav til opplæring, implementering av rutiner og prosesser, til måling og overvåkning og først deretter til fartøyets nødvendige utrustninger (arrangementer og teknologier).

Håndtering av avfall krever ved siden av gode rutiner også i de fleste tilfeller en eller flere former for behandling. Ulike avfallstrømmene kan kreve ulik behandling som vil kunne inkludere bruk av ulike teknologier. I noen tilfeller kan derimot avfallskategoriene under de tre hovedgruppene behandles på samme måte, noe som innebærer at samme type teknologi kan ha en kryssreferanse med hensyn til avfallstrømmene.

De ulike teknologiene må vurderes ut fra hva som er mest praktisk ombord med referanse til avfallskategori, regelverk og til BAT og BEP. 


\section{Innledning}

\subsection{Bakgrunn}

Det slippes ut årlig store mengder avfall i Nordsjøen til skade for fiske, havmiljøet samt fuglelivet. Utslippene forringer også områdets kvaliteter i relasjon til rekreasjon. Til tross for de eksisterende nasjonale, regionale så vel som internasjonale avtaler som forbyr dumping av avfall i marine områder, viser slik forsøpling en økende tendens. International Maritime Organization (IMO) har blant annet i den internasjonale konvensjon om hindring av forurensning fra skip 1973 med tilleggsprotokoll av 1978 (MARPOL 73/78) regulert hvordan olje (Annex I), kloakk (Annex IV) og søppel (Annex V) skal håndteres ombord på skip.

Fiskerinæringen er en av bidragsyterne til forsøplingen av de marine områdene, samtidig som forsøplingen også er en belastning for næringen både sikkerhetsmessig og økonomisk. Forsøplingen kan skyldes manglende oppmerksomhet og uvitenhet fra mannskapet ombord på fartøyene, men kan også i noen tilfeller skyldes mangel i operasjonelle rutiner og i kunnskap om regelverket, om teknologier som finnes på markedet og om mottaksordningene på land. Undersøkelser gjort tyder også på at manglende betalingsvilje er en vesentlig driver til at dumping av avfall fortsatt foregår i et betydelig omfang. Det nylig innførte EU-direktivet om mottak av avfall fra skip er vinklet for å forhindre at dette blir en motiverende faktor.

Med basis i ovenstående, er det et tydelig behov for motiverende tiltak i form av lett tilgjengelig informasjon. Den må belyse regelverket og teknologier som finnes for å håndtere avfall ombord på båtene.

Denne rapporten gir innsikt i gjeldende regelverk samt en oversikt over hjelpemidler og teknologier som finnes og som kan bidra til å sikre effektiv håndtering av avfall fra fiskefartøyer og mindre fartøyer.

\subsection{Formål}

Formålet med dette arbeidet er å formidle informasjon og kunnskap om sikker og effektiv avfallshåndtering fra denne fartøykategorien i henhold til gjeldende regelverk på dette området. Arbeidet forholder seg også til prinsippene i relasjon til beste tilgjengelige teknologier (Best Available Techniques, BAT) og beste miljøpraksis (Best Environmental Practice, BEP). 
Etablering og innføring av anbefalinger i samsvar med disse føringene, krever tilrettelegging som må tilpasses variasjonene i dette flåtesegmentet;

- variasjoner i størrelse - "store og små” fiskefartøyer og mindre fartøyer

- variasjoner i alder - nybygg versus seilende nyere og eldre fartøyer

Rapporten vil identifisere retningslinjer for avfallshåndtering ombord. Slike kan inkludere teknologier, systemer så vel som rutiner og rapportering. Disse skal bearbeides videre og presenteres i form av en informasjonspublikasjon. Målgruppen for informasjonsmaterialet vil være skipsredere, besetning og skipsverft. Informasjonspublikasjonen er dette prosjektets sluttprodukt.

\subsection{Begrensninger og definisjoner}

\subsubsection{Begrensninger}

Fiskefartøyer og mindre fartøyer omfatter alle typer fiskefartøyer, også båter som benyttes i korte perioder, dag-båter, båter med begrenset mannskap, 1-2 personer, så vel som fartøyer som er i mer kontinuerlig drift og som har en større bemanning. Lyst- og fritidsbåter er også inkludert.

Nordiske lands nasjonale regelverk hviler i stor grad på de rammer som settes av de gjeldende internasjonale konvensjonene, men ofte også tilpasset nasjonale prioriteter og øvrig nasjonalt regelverk. Følgelig kan de også avvike noe fra hverandre.

Dette arbeidet er fundamentert i gjeldende regelverk samt BEP-filosofien som tar utgangspunkt i etableringen av miljømål og videre bevisstgjøring i forhold til hvordan man kan redusere miljøkonsekvensene av fartøyets operasjoner. Dersom et BEP-mål innenfor en eller flere av avfallskategoriene av ulike årsaker ikke er mulig eller forsvarlig å leve opp til, vil gjeldende regelverk være referansepunkt.

\subsubsection{Definisjoner}

De avfallskategoriene som er diskutert inkluderer hovedgruppene olje, kloakk og søppel. Definisjonene som er benyttet i dette arbeidet refererer seg til MARPOL 73/78.

Olje er petroleum i en hvilken som helst form inkludert råolje, drivstoff (fuels), slam (sludge), oljeavfall samt andre raffinerte oljeprodukter, jf. MARPOL 73/78 Annex I, regulation 1. 
Kloakk er, jf. MARPOL 73/78 Annex IV, regulation 1;

- avløp og annet avfall fra alle former for toaletter og pissoar;

- avløp fra lokaler som benyttes til medisinske formål (skipsapotek, sykelugar, osv.) via håndvasker, badekar og spygatt som finnes i slike lokaler;

- avløp fra rom som inneholder levende dyr; eller

- annet avfallsvann når dette er blandet med avløp som definert ovenfor.

Søppel defineres som all slags mat, husholdnings- og driftsavfall eksklusive fersk fisk og deler derav, som oppstår med normal drift av skipet som en normalt kvitter seg med kontinuerlig eller periodisk med unntak av de stoffer som er definert eller oppført i andre vedlegg til MARPOL 73/78, jf. MARPOL 73/78 Annex V, regulation 1. 



\section{Regelverk}

\subsection{Innledning}

Skipsgenerert avfall fra skip er regulert gjennom den internasjonale konvensjon om hindring av forurensning fra skip, MARPOL 73/78 og dens vedlegg. Konvensjonen har som formål å hindre forurensning fra skip til det marine miljø samt i noen grad å begrense virkningene av forurensningen dersom den inntreffer. (ref. /1/)

Konvensjonen har seks vedlegg som omhandler hindring av forurensning:

- Annex I: Olje

- Annex II: Skadelige flytende stoffer i bulk

- Annex II: Skadelige stoffer pakket i gods

- Annex IV: Kloakk

- Annex V: Søppel

- Annex VI: Luft

Avfallskategoriene som her vil bli behandlet, er som tidligere nevnt olje (Annex I), kloakk (Annex IV) og søppel (Annex V).

Samtlige av de nordiske landene har ratifisert de respektive MARPOL-annekser med unntak av Island som ikke har ratifisert Annex IV. De ulike anneksene i MARPOL 73/78 definerer minimumskrav. Dette innebærer at de ulike landene eller regioner kan innføre strengere krav om ønskelig.

OSPAR-konvensjonen (Oslo-Paris Convention) ble opprettet i 1992 for beskyttelse av miljøet i Nordøst-Atlanteren og er også sentral når det gjelder håndtering av avfall ombord på skip. Annex II i konvensjonen regulerer bl.a. dumping og forbrenning av avfall og annet materiale fra skip. (ref. /2/)

EU har også utarbeidet regelverk som vil få betydning når det gjelder håndtering av avfall fra skip. Dette gjelder spesielt EUs direktiv 2000/ 59/EF endret ved direktiv 2002/84/EF, som stiller krav til mottaksordninger for avfall og lasterester fra skip med den hensikt å redusere utslipp av avfall til sjøs og dermed verne det marine miljø. (ref. /3/) Samtlige av de nordiske landene er medlem av EU eller må forholde seg til EU regelverket gjennom EØS-avtalen. Dette gjelder derimot ikke Færøyene.

HELCOM (Helsinki-Convention, 1992) trådte i kraft 17. januar 2000 og har til hensikt å beskytte Østersjø-området. I denne sammenhengen står Annex IV til konvensjonen sentralt som tar for seg utslipp fra skip. (ref. /4/) 
Det er også i varierende grad utarbeidet nasjonale regler som kan innebære ulik praksis i forhold til de ulike avfallskategoriene som dekkes i dette arbeidet i de ulike landene.

Det bør også nevnes at flere av klasseselskapene har utarbeidet miljønotasjoner som spesifiserer særlige krav utover MARPOL 73/78 så vel som nasjonale krav. Skip som har slike notasjoner forplikter seg til å etterkomme kravene i notasjonen. Kravene i slike notasjoner gjenspeiler ofte muligheter som ligger i nyere teknologier og går lengre enn kravene i etablerte regelverk.

Det er under regelverksgjennomgangen i hovedsak tatt utgangspunkt i MARPOL 73/78, men regionale og nasjonale krav er tatt med dersom disse har betydning for de operasjonelle og tekniske valg som må gjøres ombord på fartøyene for å imøtekomme gjeldende krav i de områder der fartøyene oppholder seg. Regelverket som er gjengitt i dette kapitel er kun de krav som er gjeldende for fiskefartøyer og mindre fartøyer. Krav som kun gjelder andre fartøyskategorier er derfor ikke gjengitt.

\subsection{Olje}

I MARPOL 73/78 Annex I er utslipp av olje fra skip regulert. Annex I trådte i kraft 2. oktober 1983.

\subsubsection{Utslipp av olje eller oljeholdig lensevann}

Utslipp til sjø av olje eller oljeholdig lensevann fra skip med en bruttotonnasje på 400 og derover er forbudt med mindre samtlige av punktene nedenfor er tilfredsstilt, jf. MARPOL 73/78 Annex I, regulation 9 (1) b):

- Skipet oppholder seg ikke i spesielle områder, jf. kap. 3.2.4,

- Skipet er i fart (d.v.s. underveis),

- Oljekonsentrasjonen av utslippet (ikke utvannet) overstiger ikke 15 ppm (parts per million),

- Skipet har utstyr i henhold til gjeldende tekniske krav, jf. kap. 3.2.3.

I de tilfeller der skipene har en bruttotonnasje under 400, skal de nasjonale myndighetene sikre at skipene er utstyrt så langt det er rimelig og praktisk mulig med installasjoner som sikrer lagring av oljerester ombord og dens utslipp til mottaksordninger. Utslipp til sjø i henhold til kravene beskrevet i første avsnitt i dette kapitel er lovlig, jf. MARPOL 73/78 Annex I, regulation 9 (2). 


\subsubsection{Utslipp av oljeholdig slam}

Ethvert skip med bruttotonnasje på 400 og derover skal være utstyrt med en tank eller tanker av tilstrekkelig kapasitet, tatt i betraktning typen av maskineri og reisens varighet, til å ta imot de oljerester (sludge) som ikke på annen måte kan behandles i overensstemmelse med gjeldende krav, jf. MARPOL 73/78 Annex I, regulation 17 (1).

I nye skip skal slike tanker være utført og konstruert slik at man letter rengjøringen av dem og tømmingen av rester til mottaksanlegg, jf. MARPOL 73/78 Annex I, regulation 17 (2).

Eksisterende skip skal tilfredsstille kravet så langt det er rimelig og praktisk mulig. Røropplegg til og fra tanker for oljerester skal ikke ha noen direkte forbindelse over bord, annet enn standard overbordtømmingsarrangement, jf. MARPOL 73/78 Annex I, regulation 17 (2).

Røropplegget skal legges enklest mulig og arrangeres slik at feilpumping forhindres. Det skal være separat røropplegg til dekk for levering av olje og oljeholdig vann fra maskinrom til mottaksanlegg på land, jf. MARPOL 73/78 Annex I, regulation 17 (3).

\subsubsection{Krav om tekniske løsninger}

Skip med bruttotonnasje over 400, men under 10.000 skal være utstyrt med et oljefiltreringsutstyr godkjent av nasjonale myndigheter. Oljefiltreringsutstyret skal være dimensjonert slik at konsentrasjonen av olje som slippes ut i sjøen etter å ha passert systemet ikke skal ha en oljekonsentrasjon større enn 15 ppm, jf. MARPOL 73/78 Annex I, regulation 16 (1). IMO har utarbeidet guidelines og spesifikasjoner for forurensningsforebyggende installasjoner ombord på skip, jf. Resolution MEPC.60(33). Et oljefiltreringsutstyr er normalt en lensevannsseparator.

Skip med en bruttotonnasje under 400 skal, så langt som praktisk mulig, være utstyrt med en innrettning som oppbevarer olje eller oljeholdig lensevann ombord godkjent av nasjonale myndigheter. Olje eller oljeholdig lensevann kan slippes ut dersom det gjøres i henhold til kravene beskrevet i kap. 3.2.1, MARPOL 73/78 Annex I, regulation 16.

\subsubsection{Spesielle krav}

Det gjelder spesielle krav i områder som etter MARPOL 73/78 annex I er definert som spesielle områder. Spesielle områder defineres som havområder hvor det av anerkjente tekniske årsaker i relasjon til dets oseanografiske og økologiske forhold og dets spesielle typer trafikk er nødvendig å vedta spesielle obligatoriske metoder for hindring av oljeforurensning til sjøs. Spesielle områder er etter Annex I bl.a. de Nordvesteuropeiske farvann og Østersjøen, jf. MARPOL 73/78 Annex I, regulation 10 (1).

De Nordvesteuropeiske farvann omfatter Nordsjøen, og dets innløp, Irskesjøen og dets innløp, Keltersjøen, den engelske kanal og dens innløp 
og Nordøst-Atlanteren rett vest for Irland. Område er avgrenset med linjer som binder følgende punkter sammen $48^{\circ} 27^{\prime} \mathrm{N}$ på den franske kyst;

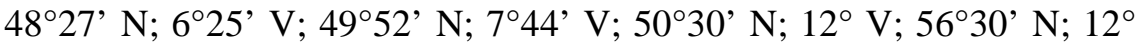
$\mathrm{V} ; 62^{\circ} \mathrm{N} ; 3^{\circ} \mathrm{V} ; 62^{\circ} \mathrm{N}$ på norskekysten; og $57^{\circ} 44,8^{\prime} \mathrm{N}$ på den danske og svenske kyst, jf. Figur 1.

Østersjøen omfatter selve Østersjøen mot den Botniske Bukt, Finskebukten og innløpet til Østersjøen avgrenset av breddegraden ved Skagen og Skagerrak ved 5844,8’ N, jf. Figur 1.

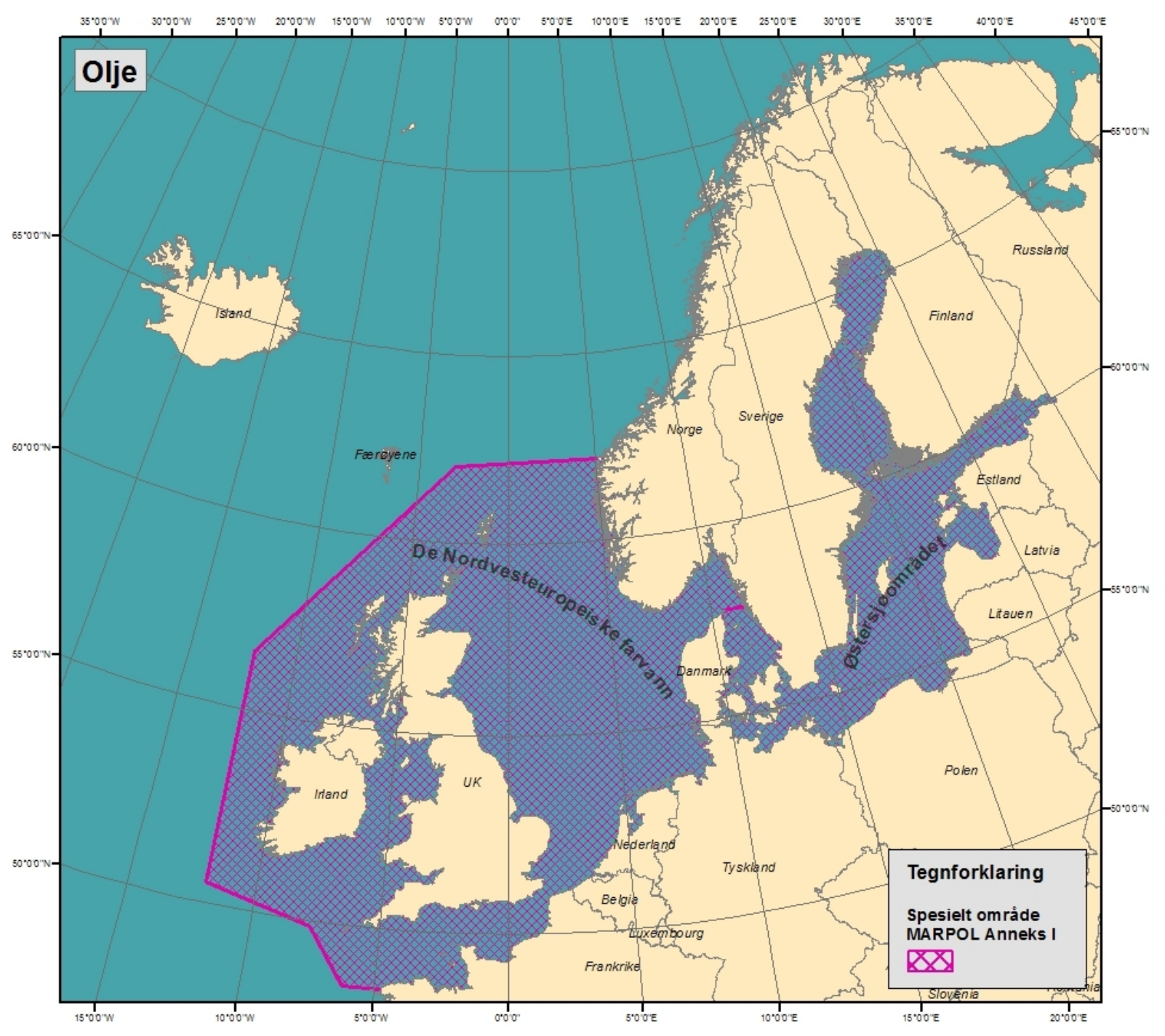

Figur 1 viser spesielle områder ved de nordiske landene for olje definert $i$ MARPOL 73/78 Annex I.

Alt utslipp til sjø av olje eller oljeholdig lensevann fra skip med en bruttotonnasje på 400, og derover er forbudt i områder definert som spesielle. Utslipp av behandlet lensevann fra maskinrommet er derimot lovlig der- 
som skipet er i fart (underveis), oljekonsentrasjonen av utslippet (ikke utvannet) ikke overstiger 15 ppm, skipet har utstyr i henhold til gjeldende tekniske krav, jf. kap. 3.2.3 samt er utstyrt med en innretning som sikrer at utslippet automatisk stopper dersom oljekonsentrasjonen overstiger 15 ppm, jf. MARPOL 73/78 Annex I, regulation 10 (2).

Utslipp av olje eller oljeholdig lensevann i spesielle områder fra skip med en bruttotonnasje under 400 er forbudt med mindre oljekonsentrasjonen er mindre enn 15 ppm, jf. MARPOL 73/78 Annex I, regulation 10 (2).

I tillegg til kravene som følger av konvensjonen, gjelder det visse nasjonale krav. For norske skip og for samtlige skip som befinner seg i norsk territorialfarvann og norsk økonomisk sone kreves det følgende tekniske løsninger i skip med bruttotonnasje på under 400, jf. norsk forskrift av 16. juni 1983 om hindring av forurensning fra skip m.m. § 2-11 (ref. /5/):

- Skip med bruttotonnasje på 200 og derover, men under 400, skal ha fastmontert oppsamlingstank plassert under dekk med røropplegg for levering av oljeholdig lensevann til mottaksanlegg.

- Skip med bruttotonnasje på 100 og derover, men under 200, skal ha fastmontert oppsamlingstank plassert under eller på dekk med røropplegg for levering av oljeholdig lensevann til mottaksanlegg.

- Skip med bruttotonnasje på 15 meter og derover, men med bruttotonnasje under 100, skal ha fastmontert oppsamlingstank plassert under eller på dekk med røropplegg for levering av oljeholdig lensevann til mottaksanlegg.

\subsubsection{Unntak}

Forbud mot utslipp av olje eller oljeholdig lensevann fra skip gjelder ikke dersom;

- utslippet er nødvendig for å vareta sikkerheten til skipet og de ombordvcerende eller berge menneskeliv til sjøs, eller

- utslippet skjer som følge av skade på et skip eller dets utstyr, dersom alle rimelige forholdsregler er tatt før og etter skaden oppstod i den hensikt å forebygge eller minimere utslippet, jf. MARPOL 73/78 Annex I, regulation 11.

\subsection{Kloakk}

\subsubsection{Innledning}

MARPOL 73/78 Annex IV regulerer håndtering og oppbevaring av kloakk på skip. Annekset trådte i kraft 27. september 2003. Det er nå blitt 
foretatt en revisjon av annex IV og det nye annekset ble godkjent 1 . april 2004 og vil tre i kraft 1. august 2005. Det er den reviderte versjonen som her beskrives.

Bestemmelsene gjelder skip i internasjonal fart større enn 400 tonn bruttotonnasje eller som er sertifisert til å ha mer enn 15 personer ombord. Det skilles mellom nye og eksisterende skip, da nye skip må forholde seg til regelverket ved ikrafttredelsestidspunktet, mens bestemmelsene gjør seg gjeldende for eksisterende skip først 5 år etter at reglene er trådt i kraft, jf. MARPOL 73/78 Annex IV, regulation 2.

Skip defineres som nye hvis byggekontrakt er plassert eller, i mangel av byggekontrakt, når kjølen er strukket eller skipet er på et lignende byggetrinn på eller etter ikrafttredelsestidspunktet eller når skipet leveres tre år eller mer etter ikrafttredelsestidspunktet, jf. MARPOL 73/78 Annex IV, regulation 1.

\subsubsection{Utslipp av kloakk}

Utslipp av kloakk til sjøen er forbudt (jf. MARPOL 73/78 Annex IV, regulation 11) med mindre skipet har;

- et godkjent oppmalings- og desinfiseringsanlegg som beskrevet i kap. 3.3.3 og utslippet foregår lengre enn 3 nautiske mil (nm) fra nærmeste land. Kloakk som ikke er oppmalt og desinfisert kan tømmes ut $i$ en avstand på mer enn $12 \mathrm{~nm}$ fra nærmeste land. Kloakk oppbevart i lagringstanker skal uansett ikke slippes ut øyeblikkelig men i moderate mengder når skipet er i fart og holder en fart på minimum 4 knop. Nasjonale myndigheter skal godkjenne utslippshastigheten basert på standarder utarbeidet av IMO.

- et godkjent kloakkrenseanlegg som beskrevet i kap. 3.3.3.

Figur 2 viser kart over de nordiske landene der $12 \mathrm{~nm}$ fra nærmeste land er markert, og som dermed viser hvilke områder som har ulike utslippskrav i følge MARPOL 73/78 Annex IV. 


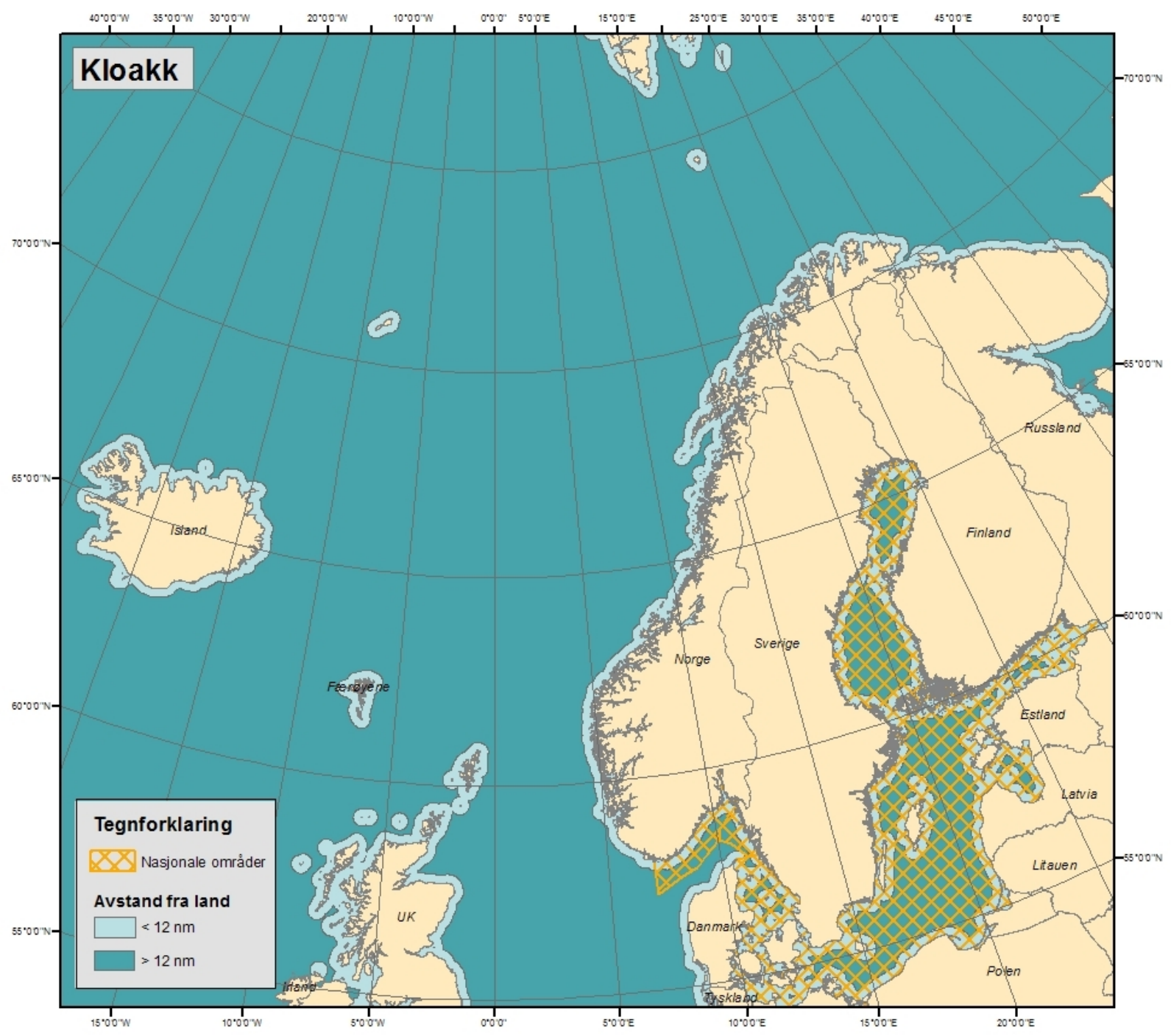

Figur 2 viser kart over de nordiske landene der $12 \mathrm{~nm}$ fra næermeste land er markert samt området som er berørt av nasjonale krav.

\subsubsection{Krav til tekniske løsninger}

Hvert skip som kommer inn under regelverket (MARPOL 73/78 Annex IV) skal være utstyrt med ett av følgende kloakkanlegg, jf. MARPOL 73/78 Annex IV, regulation 9:

- et kloakkrenseanlegg som oppfyller IMO Res. MEPC 2(VI) vedtatt 3. desember 1976; eller

- et godkjent oppmaling og desinfiseringsanlegg som har tilstrekkelig kapasitet til midlertidig oppbevaring av kloakk når skipet er mindre enn 3 nautiske mil fra nærmeste land, eller

- en oppsamlingstank med tilstrekkelig kapasitet for oppsamling av all kloakk, der det benyttes anerkjente normer ved beregningen og det tas hensyn til skipets drift, maksimalt antall personer ombord og andre 
relevante faktorer. Oppsamlingstanken skal være konstruert i henhold til konstruksjonskrav fra nasjonale myndigheter, og skal være forsynt med visuell indikering av mengden av oppsamlet kloakk i tanken.

\subsubsection{Spesielle krav}

Det er ikke definert spesielle områder i MARPOL 73/78, der det stilles strengere krav til utslipp av kloakk. Det er derimot utarbeidet noen nasjonale og regionale krav som stiller strengere krav enn MARPOL 73/78 av miljømessige hensyn.

Det er bl.a. forbudt å slippe ut kloakk i norsk sjøområde innenfor en avstand av 300 meter fra land, med unntak av skip som faller inn under MARPOL 73/78 Annex IV, jf. norsk forskrift av 1. juni 2004 om begrensning av forurensning (norsk forurensningsforskrift) § 23-4. Kommunene har mulighet til å fastsette lokale forskrifter med strengere eller lempeligere krav, jf. norsk forurensningsforskrift § 23-6 (ref. /5/).

Tømming av kloakk i norsk sjøområde sør for Lindesnes (N 57 $58^{\prime} 8$ $\varnothing 7^{\circ} 3^{\prime}$ 4) til delelinjen Norge-Danmark ( $\left.N 57^{\circ} 10^{\prime} 3 \varnothing 7^{\circ} 3^{\prime} 4\right)$ og i farvannet derfra til svenskegrensen, er forbudt, unntatt når skipet har et av følgende løsninger ombord (jf. norsk forurensningsforskrift § 23-7):

- et godkjent oppmaling og desinfiseringsanlegg som oppfyller følgende spesifikasjoner:

- oppmalt kloakk skal kunne passere en rist med største åpning 10 $\mathrm{mm}$,

- har tilstrekkelig kapasitet til midlertidig oppbevaring av kloakk når skipet er mindre enn 3 nautiske mil fra nærmeste land, der det benyttes anerkjente normer ved beregningen og det tas hensyn til skipets drift, maksimalt antall personer ombord og andre relevante faktorer,

- oppsamlingstanken skal være konstruert i henhold til konstruksjonskrav fra anerkjent klasseselskap eller gjeldende byggeforskrift, og skal være forsynt med visuell indikering av mengden av oppsamlet kloakk i tanken,

- desinfisering skal skje med egnet desinfeksjonsmiddel/saneringsvæske. Desinfeksjonsmidlet skal tilføres anlegget/tanken samtidig med kloakken. Dosering av desinfeksjonsmiddel skal følge produsentens bruksveiledning.

- et godkjent kloakkrenseanlegg som beskrevet i kap. 3.3.3.

- en oppsamlingstank som beskrevet i kap. 3.3.3.

Tømming av kloakk i finsk sjøområde og fra finske fartøyer i det øvrige Østersjøen er forbudt, unntatt når (jf. finsk förordning om förhindrande av vattens förorening, förorsakad av fartyg av 28. juni 1993 § 18) (ref. /6/): 
- finske skip har et kloakkanlegg i henhold til förordningen om marin utrustning (925/1998) eller når fartøy tilhørende EU land har et kloakkanlegg i henhold til EU-direktiv 96/98/EG om marin utrustning eller andre fartøyer har et kloakkanlegg godkjent av dens flaggstats myndigheter, eller

- skipet har et godkjent oppmalings- og desinfiseringsanlegg, og den behandlede kloakken slippes ut minst $4 \mathrm{~nm}$ fra nærmeste land, eller

- ubehandlet kloakk slippes ut lenger enn $12 \mathrm{~nm}$ fra nærmeste land og kloakk lagret i tanker skal ikke slippes ut samlet men slippes ut i moderate mengder med en minimumsfart på 4 knop.

Tømming av kloakk i svensk sjøområde og fra svenske fartøyer i det øvrige Østersjøen er forbudt, unntatt når (jf. svensk förordning om åtgärder mot vattenföroreining från fartyg av 12. desember 1985 (SJÖFS 1985/19) kap. $5 \S 4$ (ref. /7/):

- skipet har et godkjent oppmalings- og desinfiseringsanlegg, og den behandlede kloakken slippes ut minst $4 \mathrm{~nm}$ fra nærmeste land, eller

- ubehandlet kloakk slippes ut lenger enn $12 \mathrm{~nm}$ fra nærmeste land og kloakk lagret i tanker skal ikke slippes ut samlet men slippes ut i moderate mengder med en minimumsfart på 4 knop, eller

- skipet har et godkjent kloakkanlegg.

Tømming av kloakk i dansk farvann og i Østersjøområdet fra lystfartøyer kan kunne finne sted, såfremt (jf. dansk bekendtgjørelse nr. 629 af 30 . juni 2000 om regler for udtømming af kloakspildevand fra lystfartøjer, § 1) /ref. /12/:

- tømmingen foretas under anvendelse av et godkjent renseanlegg til behandling av kloakkspillvann, og spillvannet ved utløpet fra anlegget ikke frembringer synlige spor i havet, eller

- spillvannet er findelt og desinfisert i et godkjent anlegg, og utømningen skjer i en avstand av $4 \mathrm{~nm}$ fra nærmeste kyst, eller

- utømningen foretas i en avstand av minst $12 \mathrm{~nm}$ fra nærmeste kyst. Foretas utømning fra en tank til oppsamling og oppbevaring av kloakkspillvann, skal skipets fart være minst 4 knop, og utømningen skal skje med moderat utløpshastighet.

Det er forbudt å slippe ut kloakk direkte i Flensborg fjord fra skip, uansett flaggstat, som er godkjent til å ha mer enn 50 passasjerer og som seiler i fast rutefart i og på Flensborg fjord (jf. dansk bekendtgørelse nr 563 af 16. december 1985 om forbud mod udledning af kloakspildevand fra visse kategorier af skibe i Flensborg Fjord, § 2) ref. /13/. 
Figur 2 viser kart over de nordiske landene der områdene som er berørt av nasjonale krav er markert.

\subsubsection{Unntak}

Utslipp av kloakk fra skip er forbudt, med mindre (jf. MARPOL 73/78 Annex IV, regulation 3):

- kloakkutslippet er nødvendig for å vareta sikkerheten til skipet og de ombordværende eller berge menneskeliv til sjøs, eller

- kloakkutslippet skjer som følge av skade på et skip eller dets utstyr dersom alle rimelige forholdsregler er tatt før og etter skaden oppstod i den hensikt å forebygge eller minimere utslippet.

\subsection{Søppel}

\subsubsection{Innledning}

Utslipp av søppel fra skip er regulert i MARPOL 73/78 Annex V. Annekset trådte i kraft 31. desember 1988, og gjelder alle skip.

\subsubsection{Tømming av søppel}

Tømming i sjøen av alle former for plast, inklusive men ikke begrenset til syntetisk tauverk, syntetiske fiskegarn og søppelposer av plast er forbudt, jf. MARPOL 73/78 Annex V, regulation 3.

Tømming i sjøen av søppel som nevnt nedenfor skal foretas så langt som mulig fra nærmeste land, men er i alle tilfelle forbudt dersom avstanden til nærmeste land er mindre enn, jf. MARPOL 73/78 Annex V, regulation 3;

1. $25 \mathrm{~nm}$ for dunnasje, forings- og pakningsmateriale som flyter

2. $12 \mathrm{~nm}$ for matavfall og all annen søppel inklusive papirprodukter, filler, glass, metall, flasker, steintøy og lignende avfall.

Tømming til sjø kan tillates når det har gått gjennom et oppmalingsapparat eller kvern, og når tømming skjer så langt som praktisk mulig fra nærmeste land, men er i alle tilfeller forbudt dersom avstanden er mindre enn $3 \mathrm{~nm}$. Slik oppmalt eller knust søppel skal kunne passere gjennom et nett hvis åpningen ikke er større enn 25 millimeter, jf. MARPOL 73/78 Annex V, regulation 3. Dette gjelder ikke plastikk.

Når søppel er blandet med annet avfall som er underlagt forskjellige krav til tømming eller utslipp, skal det strengeste krav komme til anvendelse, jf. MARPOL 73/78 Annex V, regulation 3. 
Figur 3 viser kart over de nordiske landene der $12 \mathrm{~nm}$ og $25 \mathrm{~nm}$ fra nærmeste land er markert.

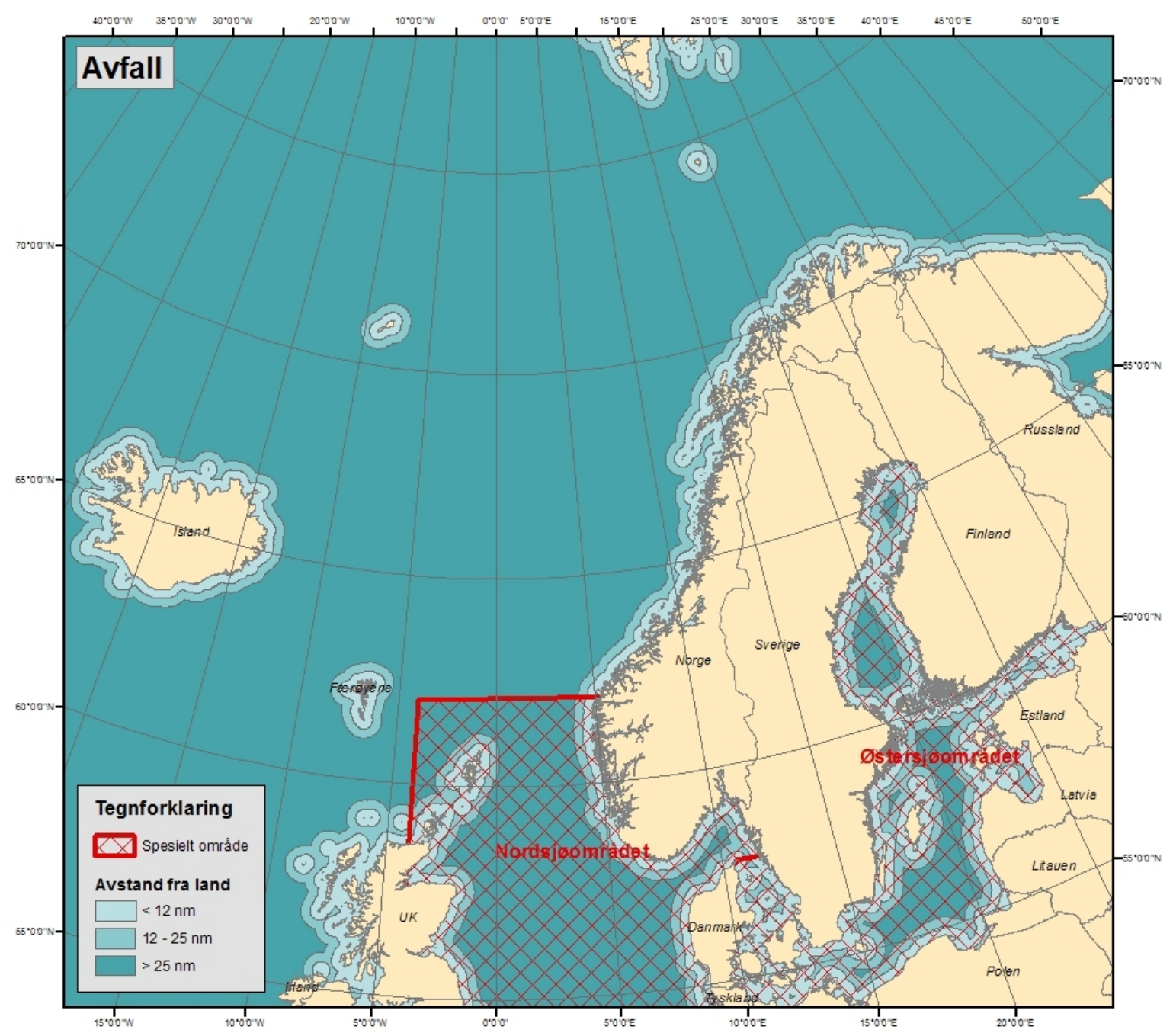

Figur 3 viser $12 \mathrm{~nm}$ og $25 \mathrm{~nm}$ fra ncermeste land samt områdene som i følge MARPOL Annex V er definert som spesielle områder.

\subsubsection{Spesielle krav}

Det gjelder spesielle krav i områder som etter Annex V er definert som spesielle områder. Spesielle områder defineres som havområder hvor det av anerkjente tekniske årsaker i relasjon til dets oseanografiske og økologiske forhold og dets spesielle typer trafikk er nødvendig å vedta spesielle obligatoriske metoder for hindring av søppelforurensning av sjøen.

Spesielle områder er etter Annex V bl.a. Østersjøområdet (selve Østersjøen med den Botniske Bukt, Finskebukten og inngangen til Østersjøen avgrenset av breddegraden ved Skagen i Skagerak ved 57 $44,8^{\prime} \mathrm{N}$ ), Nordsjøområdet (selve Nordsjøen, innenfor grensene for havområdet sør 
for $62^{\circ} \mathrm{N}$ og øst for $4^{\circ} \mathrm{V}$, Skagerrak, den sydlige grensen øst for Skagen ved $57^{\circ} 44,8^{\prime} \mathrm{N}$ og Den engelske kanal øst for $5^{\circ} \mathrm{V}$ og nord for $48^{\circ} 30^{\prime}$ N), jf. MARPOL 73/78 Annex V, regulation 5.

Figur 3 viser spesielle områder definert i MARPOL 73/78 Annex V. I spesielle områder er det forbudt å tømme følgende i sjøen:

1. All plast, deriblant syntetisk tauverk, syntetiske fiskegarn og søppelposer av plast.

2. Alt annet søppel, med unntak av matavfall.

Tømming av matavfall i sjøen skal foregå så langt fra land som praktisk mulig, men i alle tilfeller ikke mindre enn $12 \mathrm{~nm}$ fra nærmeste land.

Figur 3 viser $12 \mathrm{~nm}$ og $25 \mathrm{~nm}$ fra nærmeste land samt områdene som i følge MARPOL Annex V er definert som spesielle områder.

Det stilles spesielle krav til utslipp av søppel i nærheten av faste eller flyttbare plattformer, da det ikke er lov å tømme søppel innenfor 500 meter fra plattformen selv om den ligger mer enn $12 \mathrm{~nm}$ fra nærmeste land. Tømming av matavfall kan tillates innenfor 500 meter når det har gått gjennom et oppsamlingsapparat eller en kvern og plattformen ligger mer enn $12 \mathrm{~nm}$ fra nærmeste land. Slik oppmalt eller knust søppel skal kunne passere gjennom et nett hvis åpningen ikke er større enn 25 millimeter, jf. MARPOL 73/78 Annex V, regulation 4.

\subsubsection{Unntak}

Forbudet mot utslipp av søppel fra skip kommer ikke til anvendelse dersom:

- søppelutslippet er nødvendig av hensyn til skipet og de om bordværende sin sikkerhet eller for å redde liv til sjøs, eller

- søppelutslippet skjer som følge av skade på et skip eller dets utstyr dersom alle rimelige forholdsregler er tatt før og etter skaden inntraff $i$ den hensikt å forhindre eller begrense utslippet til det minst mulige, eller

- utilsiktet tap av syntetiske fiskegarn, forutsatt at rimelige forholdsregler er blitt tatt for å forhindre slike tap.

\subsection{Forbrenning av avfall}

OSPAR konvensjonens Annex II forbyr forbrenning av søppel og annet materiale ombord på skip. Dette gjelder derimot ikke forbrenning av avfall som er knyttet til eller skriver seg fra vanlig drift av skip, innretning eller utstyr ombord på disse. 
HELCOM regulerer også mulighetene for forbrenning av avfall ombord i Østersjøen. Det er i følge HELCOM ikke lov å forbrenne avfall ombord på skip i Østersjøen, jf. HELCOM Annex IV, regulation 7.

\subsection{Mottaksordninger på land}

MARPOL 73/78 Annex I, IV og V stiller samtlige krav om at landene skal ha mottaksordninger på land for håndtering av olje, kloakk og søppel. EUs direktiv 2000/59/EF endret ved direktiv 2002/84/EF stiller også krav til mottaksordninger for avfall og lasterester fra skip med den hensikt å redusere utslipp av avfall til sjøs og dermed verne det marine miljø.

Havneansvarlig skal ut fra behovet for levering, sørge for etablering og drift av mottaksordninger for avfall og lasterester fra skip i havnen. Mottaksordningene skal være tilstrekkelige til å dekke et normalt behov for levering i havnen, uten at skipene forsinkes unødig, jf. EU direktiv 2000/59/EF artikkel 4.

Skipsfører på alle skip som er underveis til havn innenfor EU-området, med unntak av rutegående skip og fritidsbåter godkjent for høyst 12 personer, skal gi melding om levering av avfall og lasterester i havnen til havneansvarlig minst 24 timer før anløp, eller så snart havneanløpet er kjent dersom denne opplysningen først blir kjent mindre enn 24 timer før anløp og senest ved avgang fra forrige havn dersom reisen varer mindre enn 24 timer, jf. EU direktiv 2000/59/EF artikkel 6.

Omkostningene forbundet med mottak og videre håndtering av avfall fra skip, skal dekkes ved innkreving av avfallsgebyrer fra de skip som anløper havn. Gebyret skal innkreves uavhengig av om det leveres avfall fra skipet til mottaksordningen. Gebyret skal differensieres ut fra tilbudet av mottaksordninger. Gebyret kan innkreves av havneansvarlig for hvert anløp eller som årsgebyr, sesonggebyr eller liknende. Fritidsbåter for høyst 12 personer og fiskebåter skal ikke avkreves gebyr ved anløp, med mindre de også plikter å betale havneavgift eller annet gebyr, jf. EU direktiv 2000/59/EF artikkel 8.

Det gis fradrag i gebyr dersom skipets miljømessige konstruksjon, utstyr eller drift på en ikke uvesentlig måte bidrar til at, jf. EU direktiv 2000/59/EF artikkel 8;

- mengden avfall fra skipet til mottaksordningen reduseres,

- håndtering av avfallet fra skipet blir rimeligere på land,

- avfallet leveres fast på en annen havn, eller

- særlige hensyn tilsier det.

Skipsfører skal sørge for at avfall og lasterester fra skipet blir levert til mottaksordning i havn før avgang, med mindre det er gitt melding om at levering ikke vil forekomme i forkant, at det er avsatt tilstrekkelig lag- 
ringskapasitet for avfall og lasterester fra skipet inntil det blir levert til mottaksordning. For oljeholdig avfall skal det være en restkapasitet på minst $75 \%$ av totalkapasiteten, jf. EU direktiv 2000/59/EF artikkel 7. 


\section{$4 \mathrm{BAT} / \mathrm{BEP}$}

BAT (Best Available Techniques) og BEP (Best Environmental Practice) er begreper som anbefales lagt til grunn for valg av teknologi for avfallshåndtering også ombord i skip, herunder de fartøyskategoriene som dette arbeidet dekker.

Vi har tidligere sett at det internasjonale regelverket som regulerer avfallshåndtering i skipsfarten er minimumsregler og videre at nasjonale forskrifter i stor grad hviler på disse, men går noen ganger lengre og er mer nyanserte. Filosofien bak BAT/ BEP- begrepene går enda lengre og kan ses på som verktøy der referansene er relatert til et områdets reelle behov for beskyttelse (BEP) og den virkelige mulighet til å oppnå slik tilstrekkelig beskyttelse (BAT) istedenfor begrensninger i regelverk som ofte har referanse til generiske betraktninger.

For å kunne forstå grunnlaget for det vi setter som målestokk for utslipp, defineres nedenfor de ulike begrepene.

BAT er et begrep som er definert i Rådsdirektiv 96/61/EF av 24. september 1996 om integrert forebygging og begrensning av forurensning (IPPC direktivet) som det mest effektive og avanserte steg i utviklingen av virksomheten og deres driftsmetoder, som indikerer den praktiske egnetheten til bestemte teknikker til å være grunnlag for utslippsgrenseverdier med sikte på å forebygge og dersom dette ikke er mulig, generelt begrense utslippene og innvirkningen på miljøet som helhet. (ref. /8/)

Med teknikker menes både den anvendte teknologi og måten anlegg konstrueres, bygges, vedlikeholdes, drives og avvikles på. Med tilgjengelig teknikker menes de som er utviklet i en slik målestokk at de kan anvendes i den aktuelle industrien på økonomiske og tekniske mulige vilkår, og de beste teknikker er de som er mest effektive i forhold til å oppnå et høyt allment vernenivå for miljøet som helhet.

Forhold som skal tas i betraktning i alminnelighet eller i et bestemt tilfelle ved fastsettelse av de beste tilgjengelige teknikker står listet opp under, jf. IPPC direktivet:

1. Bruk av teknologi som gir lite avfall

2. Bruk av mindre farlige stoffer

3. Fremming av teknikker for gjenvinning og resirkulering av stoffer som produseres og benyttes i prosessen, og eventuelt av avfall

4. Prosesser, utstyr eller driftsmetoder som kan sammenlignes, og som er utprøvd med godt resultat i industriell målestokk

5. Den tekniske utvikling og ny vitenskapelig erkjennelse

6. De aktuelle utslippenes art, virkninger og omfang

7. Datoene for igangsetting av nye eller eksisterende anlegg 
8. Det tidsrom som er nødvendig for å innføre de beste tilgjengelige teknikker

9. Forbruket og arten av råstoffer (herunder vann) som benyttes i prosessen, og deres energieffektivitet

10. Behovet for å forebygge eller minimere den samlede miljøpåvirkning som utslippene medfører eller innebærer risiko for å medføre

11. Behovet for å forebygge ulykker og begrense følgene av dem for miljøet

12. De opplysninger som offentliggjøres av Kommisjonen i henhold til artikkel $16 \mathrm{nr} .2$ eller av internasjonale organisasjoner.

BAT i relasjon til håndtering av avfallstrømmene ombord i mindre fartøyer og fiskefartøyer vil måtte ses i lys av den filosofi som legges til grunn for miljøvennlig operasjon og drift. Den praksis som så må etableres kan defineres gjennom vurderinger $\mathrm{i}$ henholdt til det konseptuelle BEP.

BEP vil i relasjon til de utfordringer dette arbeidet henveder seg mot, stå for den praksisen som;

- sikrer gode helsebetingelser for de ansatte; og

- reduserer påvirkningen på miljøet og reduserer utslippet av skadelige stoffer til havet og som gagner miljøet på best mulig måte.

BEP kan for eksempel basere seg på at alt avfall generert ombord skal leveres til mottaksanlegg på land. I et videre perspektiv vil en slik strategi måtte forutsette at avfallet kan oppbevares ombord på en forsvarlig måte både med referanse til mannskapet helse og eventuelle implikasjoner i relasjon til miljøet og videre til mottaksordningenes kvalitative evne til å håndtere avfallet på tilsvarende forsvarlig måte. Det synes rimelig å forvente at dette siste punktet kan antas ivaretatt der havner i henhold til krav fra myndigheter har etablert mottaksordninger.

For å velge den best tilgjengelige teknologien bør utgangspunktet være å definere den mest miljøvennlige praksisen som lar seg implementere ombord i skip. Denne praksisen må kvalitetssikres ved at den kontrolleres opp mot gjeldende regelverk. Dersom den finnes å være i overensstemmelse med slike, blir et neste steg å definere løsninger som muliggjør etterlevelse av slik praksis. Der slike løsninger involverer bruk av teknologi, vil slik i denne sammenheng kunne representere BAT dersom teknologien i seg selv tilfredsstiller punktene gjengitt over med referanse til IPPC-direktivet. De teknologiene som viser best resultater og egner seg best ombord i fiskefartøyene bør så velges. Det er også et krav om at teknologien skal være kostnadsnyttig. 


\section{Teknologier}

\subsection{Innledning}

Det finnes ulike behandlingsformer når det gjelder håndtering av avfall, noe som også kommer frem i gjeldende regelverk, jf. kap. 3. Avfallspyramiden, som vist i Figur 4, viser hvilke avfallsbehandlingsformer som kan tas i bruk vedrørende håndtering av avfall. Den minst foretrukne behandlingsform ligger nederst og mer ønskelig disponering av avfallet oppover i pyramiden.

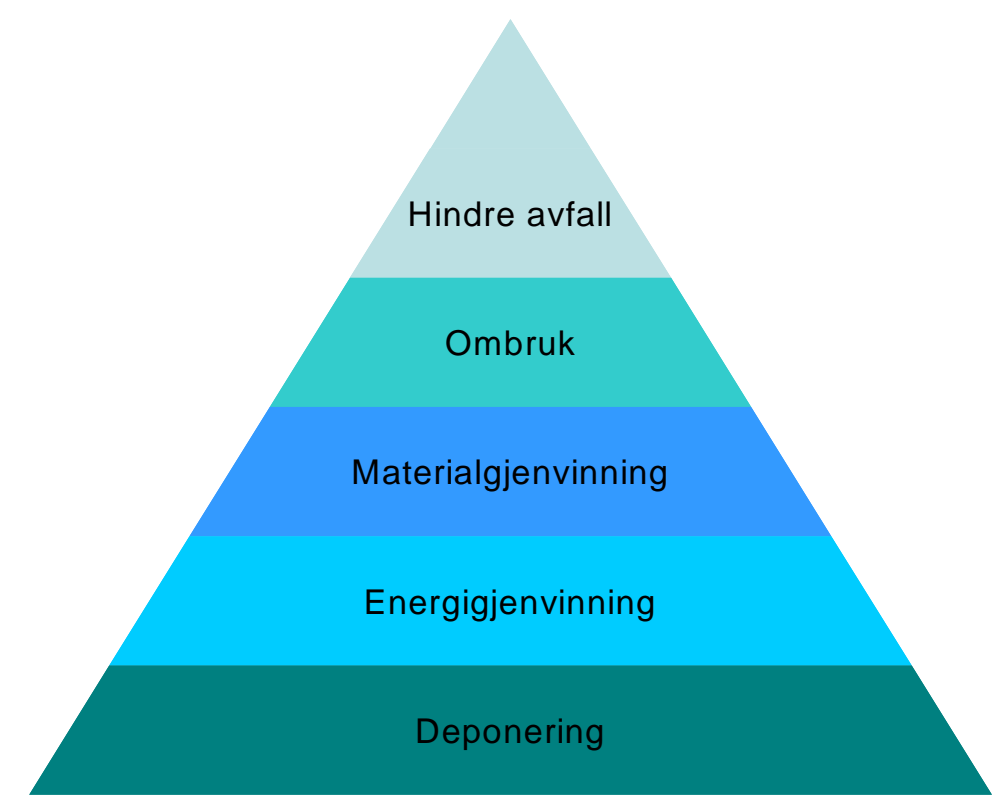

Figur 4. Avfallspyramiden

Hovedstrategien som ligger til grunn for Figur 4 er å:

1. Hindre at avfall oppstår og redusere mengden av skadelige stoffer i avfallet

2. Fremme ombruk, materialgjenvinning og energiutnyttelse

3. Sikre en miljømessig forsvarlig sluttbehandling av restavfallet 
Det er denne filosofien som ligger til grunn for definisjonen av BEP i denne sammenheng, og som vil ligge til grunn for valg av teknologi for håndtering av avfallet ombord i fiskebåter og mindre fartøyer.

Generelt kan det hevdes at de ulike avfallskategoriene krever ulik behandling. Imidlertid har vi sett at flere av avfallskategoriene kan behandles på samme måte, se Figur 5. Altså kan samme teknologi ha en kryssreferanse med hensyn til avfallstrømmene.

De ulike teknologiene må vurderes ut fra hva som er mest praktisk ombord med referanse til avfallskategori, regelverk og til BAT og BEP.

Større skip og skip med større besetninger vil normalt generere større avfallsvolum og kanskje også mer komplekse avfallstrømmer. Likeledes vil forhold knyttet til avfallshåndtering divergere mellom eldre og nyere skip. I noen tilfeller vil det ikke være mulig å vurdere en enkelt teknologi isolert men snarere å se avfallshåndteringen ombord som et system som setter krav til både rutiner og praksis så vel som til teknologier.

Betingelsene knyttet til definisjonen av BAT kan legges til grunn for å bestemme hvilken teknologi som er best egnet $\mathrm{i}$ isolerte tilfeller. De kravene som likevel må tilfredsstilles er nasjonale og internasjonale regler.

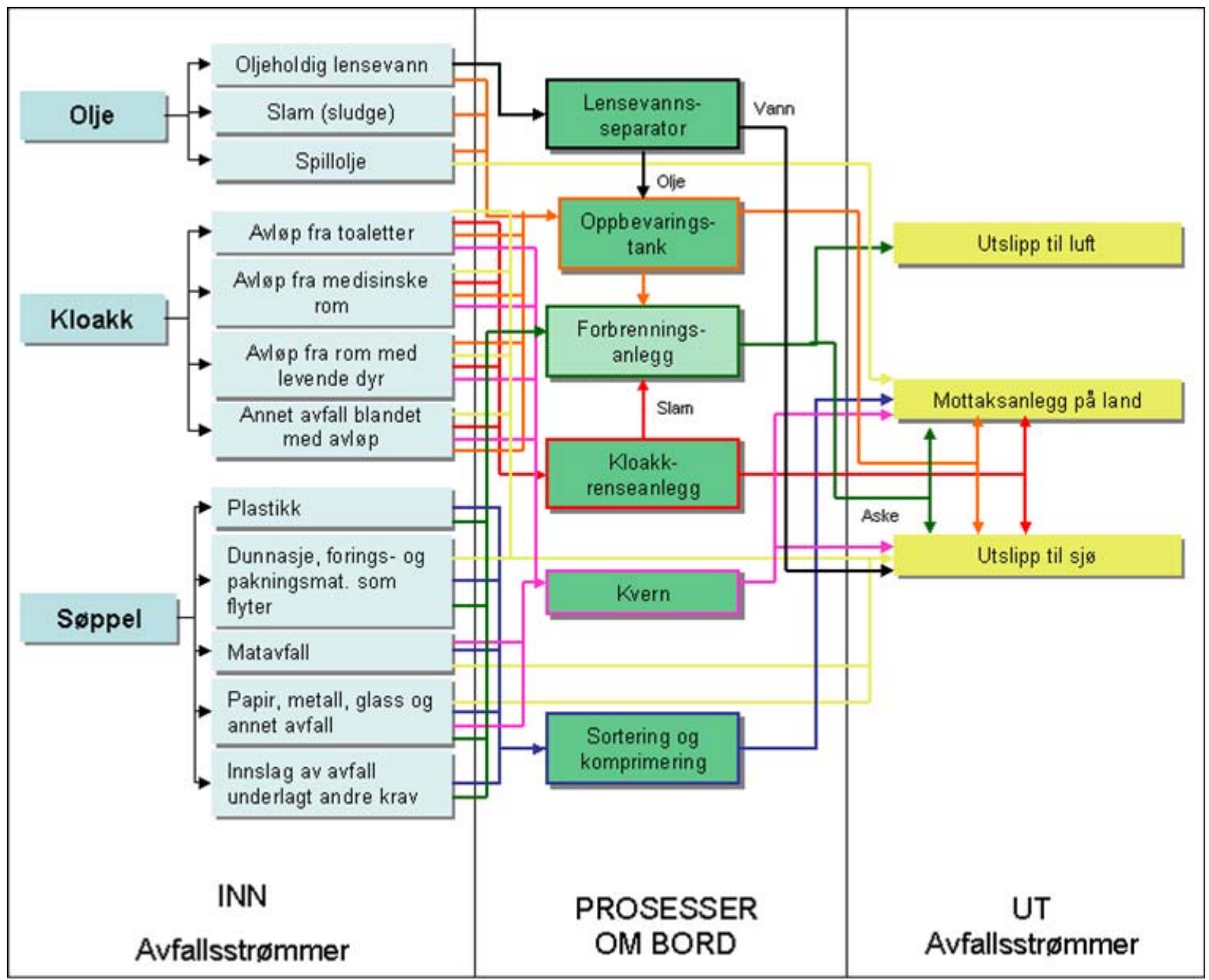

Figur 5. Avfallsstrømmer knyttet til olje, kloakk og søppel. 


\subsection{Oljeholdig avfall}

Fast oljeholdig avfall er rester som filler, twist pakninger, slanger og annet materiale som er forurenset av olje. Det kan også være bunnfall fra bunkerstanker som ofte er en blanding av rust og andre partikler. Slikt avfall blir ofte forbrent i skipets forbrenningsovner dersom slikt er installert. Forbrenningsovner finnes oftest kun ombord i større fartøyer og er dessuten underlagt restriksjoner med hensyn til bruk, jf. kap. 3.5. Slikt avfall må derfor også forventes å måtte samles inn for så å leveres til mottaksanlegg.

Spillolje er brukte oljer og samles opp ettersom olje skiftes ut. Olje fra lekkasje samles opp og kommer inn under kategorien spillolje. Slike restprodukter kan i noen tilfeller inneholde relativt store mengder vann.

Oljeholdig lensevann er forurenset vann som samles opp i skutebunn eller på tanktopp i maskinromsområdet. Lensevannet kan inneholde inntil $10 \%$ olje. Lensevann inneholder ofte også kjemikalier og løsningsmidler, eksempelvis midler benyttet til vasking av maskinerier.

Oljeholdig slam er nok en kategori oljeholdig avfall som kan være forurenset med andre stoffer (sand, partikler, vann, m.m.).

Spillolje, lensevann og oljeholdig slam kan samles i oppbevaringstank, eventuelt skilles spillolje fra de to andre kategoriene for så å leveres direkte til mottaksanlegg for prosessering. Mottaksordninger for spillolje setter ofte krav til oljekvaliteten (andel innslag av vann). Lensevannsseparatorer er ofte installert og skiller olje fra vann med en renhetsgrad som tillates sluppet ut (15 ppm, jf. kap. 3.2.1). Restoljen føres så til en oppbevaringstank.

Etter at IMO i august 1999 erklærte Nordsjøen syd for $62^{\circ} \mathrm{N}$ som såkalt spesielt område har det blitt påbudt med en innretning ombord som måler oljemengden og som stopper utslippet dersom lensevannet har et oljeinnhold på mer enn 15 ppm, jf. kap. 3.2.4. Slike oljemengdemålere kan leveres ferdig montert på nye lensevannsseparatorer, eller som ekstrautstyr på eksisterende lensevannsseparatorer for å tilfredsstille gjeldende IMO-krav. Det finnes kompakte lav-kapasitets lensevannsseparatorer egnet for mindre fartøyer også for ettermontering.

\subsection{Kloakk}

Kloakk er ofte benyttet som et samlebegrep for sortvann (kloakk) og gråvann. Disse to komponentene er begge avløp fra skipets "husholdning" men er ulike i substans og har derfor ulike behandlingsbehov. Imidlertid er det ikke alle skip som differensierer mellom de to, men som samler alt slikt avløp til ett. Merk at isolert sett er ikke gråvann regulert i MARPOL 73/78 Annex IV. MARPOL 73/78 setter krav til godkjente behandlingsanlegg for kloakk, jf. kap. 3.3.3. 


\subsubsection{Teknologier}

Det er i kap. 3.3.3 beskrevet tre ulike metoder for håndtering av kloakk som problemavfall. Disse er:

- Behandling av kloakk ved bruk av et godkjent kloakkrenseanlegg.

- Bruk av et godkjent system for oppmaling og desinfisering av kloakken.

- Oppbevaring av kloakk ombord i en lagringstank.

Det finnes også metoder for å redusere volumet av kloakk. Merk også at ulike behandlingsalternativer kan kombineres opp mot ulike filtreringsteknologier inkludert screening, membranteknologi, m.m.

\subsubsection{Kloakkrenseanlegg}

I kloakkrenseanlegg inngår normalt ulike behandlingsfaser;

- Forberedende behandling

- Rensebehandling

- Håndtering av sluttproduktene

De fleste kloakkrenseanlegg inkluderer en oppsamlingstank. Herfra mengdedoseres massen inn til rensebehandling ofte via en filtreringsprosess. Denne forberedende behandlingen separerer større partikler fra væskefasen. Selve rensebehandlingen benytter biologiske, kjemiske metoder eller elektrokjemiske prinsipper. Sluttproduktene av disse to trinnene er henholdsvis en vannfase samt slam. Vannfasen kan etterbehandles kjemisk eksempelvis ved klor. I mange tilfeller vil det være uønsket eller også ulovlig å benytte kjemikalier. Et alternativ til klor kan da være UVbestråling. Vann fra kloakkrenseanlegg kan normalt pumpes over bord. Slamfasen behandles i noen tilfeller også kjemisk. Imidlertid er denne ofte av en slik konsistens at det ikke er nødvendig. Slam kan leveres til mottaksanlegg, pumpes over bord i enkelte områder der dette er tillatt, eventuelt brennes i et forbrenningsanlegg.

Biologisk behandling er den mest anvendte metoden med en markedsandel på om lag 70 \% i Europa. Det finnes 5-6 store produsenter av slike anlegg i Europa. Nedenfor er oppsummert noen av disse:

- Hamworthy (England)

- Aquamar and Saltzkotten (Tyskland)

- Isir (Italia)

- Scanship Engineering (Tønsberg)

I et bio-anlegg for kloakkbehandling blir organisk materiale som partikler oppløst i væske (slam) og blir "føde” for mikro-organismer som produserer andre mindre komplekse stoffer samt celle-masse. Dette er så separert 
fra væskefasen som biologisk slam. Slik biologisk behandling er effektiv for fjerning av store og mindre partikler så vel som organisk materiale. Evnen til å fjerne fosfor er imidlertid ganske moderat. Metoden kan også anvendes for fjerning av nitrogen. De fleste leverandørene av bio-renseanlegg leverer systemer basert på aerobisk behandling der kloakken tilføres luft. Dette gjøres for å akselerere de biologiske nedbrytningsprosessene. Restproduktet, slam, er nærmest fri for bakterier og kan derfor normalt tillates sluppet ut direkte der dette er lov.

Kjemiske behandlingsmetoder benytter kjemikalier for å forandre avfallstrømmens konsistens slik at separering av faststoff og væske blir enklere. Slik separasjon foregås som regel ved sedimentering (gravitasjonsseparasjon). Både faststoff og væske behandles videre. I behandlingen kan inngå videre bruk av kjemikalier samt tørkeprosesser. Restproduktene, slam og vann, håndteres på tilsvarende måte som for biologiske anlegg.

Elektro-kjemisk behandling av kloakk innebærer normalt elektrokjemisk oksidasjon og en relativt ny metode for om bord håndtering. Slike anlegg er kommersielt tilgjengelig, men relativt få installasjoner er foretatt.

Kloakkrenseanlegg beregnet for skip finnes i størrelsesorden fra 10 personer og oppover. Det er imidlertid funnet en leverandør av slik anlegg som kan levere ned til 6 personer. Noen av anleggene kan håndtere gråvann blandet med sortvann. Biologiske anlegg er spesielt sårbare for dette og bør derfor ha separat tilførsel av disse to fasene. Hovedårsaken til dette er at en del prosesser påvirkes av tilstedeværelse av såperester (fettløsende midler).

Behandlingsanlegg for kloakk for inntil 10 personer kan koste i størrelsesorden 10.000 euro. I tillegg kommer installasjonskostnader. I fartøyer med krav til maskinist ombord antas det ikke å være behov for opplæring i tilknytning til operasjon og drift av slike anlegg. Moderne små kloakkrenseanlegg er meget kompakte og lite energikrevende. Mindre fartøyer installerer slike anlegg i økende grad, eksempelvis mindre ferger.

\subsubsection{Oppmaling og desinfisering av kloakk}

Oppmaling og desinfisering av kloakk kan være et alternativ til en mer fullstendig renseprosess.

Ved oppmaling av kloakk blir de største partiklene kvernet til finere partikler for deretter å gjennomgå en eller annen form for desinfisering. De mest benyttede metoder for slik desinfisering er:

- Klorinering

- Behandling med $\mathrm{O}_{3}$ (ozon)

- Bestråling med Ultra-Violet lys (UV) 
Bruk av klor er hyppigst anvendt enten i form av gass $\left(\mathrm{Cl}_{2}\right)$ eller i form av fast materiale.

Oksidasjon ved bruk av ozon $\left(\mathrm{O}_{3}\right)$ er et effektivt middel for desinfisering og i tillegg svært egnet m.h.t. fjerning av lukt. Ozon produseres på stedet der det anvendes ved spalting av oksygen $\left(\mathrm{O}_{2}\right)$ fra luft ved å sette opp et spenningsfelt. Ozon er svært ustabilt og har en kort halveringstid. Det knytter seg derfor en del begrensninger til bruk av ozon, noe som gjør slike anlegg relativt kostbare. Tidlige ozonanlegg hadde en del arbeidsmiljømessige implikasjoner. Slike moderne anlegg har imidlertid innbygget sikkerhetsanordninger som nå gjør disse trygge. Ozon forårsaker oksidasjonsprosesser og er derfor assosiert med risiko for øket korrosjon.

Utra-Violet bestråling benytter et spektrum av lys i frekvensområde 100-4,000 Ångstrøm (1 Ångstrøm $10^{-10} \mathrm{~m}$ ). UV bestråling har en demonstrert desinfeksjonsevne men har begrenset anvendelse. Dette er hovedsakelig grunnet anskaffelseskostnader samt krav til vedlikehold.

Etter behandling som over, kan avfallsproduktene normalt pumpes over bord.

Det er derimot viktig å merke seg en økende skepsis til vannbehandling ombord i skip som inkluderer bruk av kjemikalier. Det finnes særbestemmelser som forbyr slike utslipp.

\subsubsection{Oppbevaringstank for kloakk}

Tanker for oppbevaring av kloakk finnes ombord i svært mange skip. Kloakken leveres til mottaksanlegg på land etter behov (og anledning). Kloakken kan også slippes ut når skipet befinner seg i områder der dette er lov slik definert i MARPOL 73/78 Annex IV eller gjennom nasjonale/ regionale forskrifter, jf. kap. 3.3. Slike tanker bør ha overvåkningssystemer slik som nivåkontroll. Dersom tankene tømmes i farvann der dette tillates, bør det anordnes et arrangement som gjør det mulig å overvåke utslippsrate i henhold til krav om dette.

Fartøyer som slipper ut oppkvernet kloakk har også som regel oppbevaringstanker installert.

\subsection{Søppel}

I perioden fra 1975 til 2002 økte gjennomsnittlig husholdningsavfall per person fra $175 \mathrm{~kg}$ til $354 \mathrm{~kg}$ årlig. Andel materialgjenvunnet avfall i periode 1992 til 2002 økte fra $9 \%$ til $45 \%$. Mengde næringsavfall er redusert noe de siste årene. Dette skyldes mest sannsynlig endringer i produksjonsprosesser som gir mindre avfall (produksjon av mat). Samtidig som forbruket $\mathrm{i}$ vår del av verden har hatt en sterk vekst har altså andel gjenbruk økt dramatisk. Landsidens evne til å håndtere avfall er sterkt forbedret og kildesortering er innført i relativt sett stort omfang. Dette er imid- 
lertid ikke nødvendigvis tilfelle i relasjon til søppel generert ombord i skip (ref.: MARPOL 73/78 Annex V, regulation 4 og 5). Det kan antas at mottaksapparatene på land i stor grad kan ta imot og videre distribuere sortert avfall.

Tiltak som reduserer avfallsmengde, motiverer til ombruk, og gjenvinning reduserer behov for forurensende behandlingsmetoder som forbrenning og deponering. Dermed oppnås mindre forurensning fra avfallsbehandlingen. I tillegg får vi ekstra gevinster ved at forbruket av nye ressurser og dermed også energiforbruk/forurensning går ned.

Ved materialgjenvinning kan materialer brukes som råstoff i ny produksjon samtidig som energiforbruket ofte reduseres i forhold til produksjonen fra nytt råstoff.

Det finnes flere nasjonale regelverk som forbyr all utslipp av søppel fra skip til sjø. Blant annet har the Canadian Shipping Act et slikt generelt forbud som dekker alle havområder under Kanadisk jurisdiksjon. I vår sammenheng, vil en slik null-tolleranse kunne hevdes å representere BEP dersom avfallet er sortert. Man forutsetter da imidlertid at kvalifiserte mottaksordninger på land finnes i tilstrekkelig grad.

Avfallreduksjon vil være et initiert virkemiddel nærmest uavhengig av hvordan man arrangerer håndteringen av avfallstrømmene. En bevist holdning til avfallsminimering vil ofte føre til redusert forbruk og derigjennom gi en økonomisk gevinst. Videre vil mindre avfall kreve mindre resurser enten man håndterer avfallet selv eller om man leverer det til mottaksanlegg. Dersom skipet innfører ordninger eller arrangementer som reduserer avfallsvolumet, kan en oppnå fradrag i gebyrer ved levering til mottaksordninger, jfr. kap. 3.6.

\subsubsection{Avfallskategorier}

Avfallkategoriene representert i søppel kan typisk deles inn i gruppene;

1. Plastikk

2. Papir

3. Metall

4. Glass

5. Matavfall

6. Restavfall

7. Spesialavfall

Det er kun kategori 5 som ikke kan lagres over tid (uten at det tas spesielle forhåndsregler). Videre kan alle de andre avfallskategoriene resirkuleres med noen unntak i relasjon til plast.

Hovedutfordringen for avfallshåndteringssystemer der man adopterer BEP-filosofien, jf. kap. 2.3.1, blir altså avfallsreduksjon, oppbevaring og sortering. Implementering av kildesortering krever i alminnelighet et til- 
tak ved kilden samt etablering av en praksis som sikrer mot opphoping ved kilden og sikker lagring.

\section{Kildesortering;}

Rutiner for kildesortering må tilpasses og etableres der avfall genereres. Slike steder er typisk bysse, oppholdsrom, proviantlager, maskinrom, toaletter, vaskerier, etc. Fasiliteter må anordnes på alle slike steder for å gjøre sortering effektiv og hensiktsmessig. Videre må det etableres rutiner som sikrer at avfallstrømmene fra de ulike kildene samles opp tilstrekkelig hyppig og bringes sammen til felles oppbevaring avskilt i respektive avfallskategorier.

\section{Oppbevaring;}

Effektiv resirkulering hviler helt og fult på skikkelig sortering. Derfor blir lagring av respektive avfallskategorier vesentlig. Dette bringer inn to utfordringer når vi skal etablere slike ordninger for skip;

- Plass - fiskefartøyer og mindre fartøyer nærmest uavhengig av "type” er ofte i utgangspunktet svært godt utnyttet med hensyn til plass.

Videre er ikke alle områder i et skip like anvendelige for lagring av avfall.

- Komprimere - grunnet plassmangel blir det viktig å redusere avfallsgenerering med hensyn til volum. Dette kan angripes ved å;

- Redusere forbruk - dette er et kostnadsrelatert spørsmål. Det kan ofte antas at det alminnelige forbruket er på et normalnivå og representerer ikke et vesentlig potensielt ytterligere bidrag.

- Redusere emballasje - ved siden av forbruksmateriell er en vesentlig del av avfallstrømmen emballasje. Det er en stadig økende tendens at man får levert varer nærmest i bulk slik at volumkrevende emballasje ikke tas ombord.

- Avfallskomprimering - de ulike avfallsgruppene har ulike potensialer med hensyn til volumreduksjon. Eksempelvis finnes det et stort utvalg av systemer for komprimering av papir, reduksjon av volumet av glass ved kverning, osv.

Organisk avfall som ikke er i væskeform og som derfor ikke kategoriseres som gråvann kan representere en kilde til resirkulering gjennom eksempelvis kompostering, imidlertid er dette normalt ikke hensiktsmessig ombord i et fartøy. Slikt avfall setter krav til lagring og kan representere en kilde til spredning av lukt, etc. dersom lagring ikke gjennomføres forskriftsmessig. Alternativt til lagring er behandling ved oppkverning i kombinasjon med utvanning. Slik oppmalt eller knust søppel kan slippes ut, dersom det er mer enn $3 \mathrm{~nm}$ fra nærmeste land og det kan passere gjennom et nett hvis åpningen ikke er større enn 25 millimeter, jf. kap. 
3.4.2. Eventuelt kan slikt avfall gå i skipets avløp som gråvann, alternativt følge håndteringsrosessene knyttet til kloakk.

\subsubsection{Teknologier}

\section{Returordninger}

Sortering og levering til mottaksanlegg kan synes lite hensiktsmessig dersom apparatet på mottakersiden ikke er satt opp med tilstrekkelig infrastruktur til å håndtere videre prosesser på en optimal måte. Ulike land har ulike strategier i relasjon til returordninger. Det må i midlertidig antas at disse etter hvert utvikles på en slik måte at man kan anta at leveranser fra skip til returordningene representerer en "optimal” håndtering så langt skipene selv kan påvirke avfallshåndtering. EUs mottaksdirektiv vil være med på å bedre mottaksordningene på land, jf. kap. 3.6.

\section{Plastikk}

Plastemballasje kildesorteres ombord (hos avfallsbesitter) i definerte fraksjoner;

- Folie

- Flasker/ kanner

- PP-sekk

- EPS

Disse fraksjonene leveres så til mottaksanlegg som kontrollerer, eventuelt ettersorterer, presser og videresender til material- eller energigjenvinner. Imidlertid er ofte mangfoldet i denne avfallskategorien så omfattende at det av praktiske årsaker samles inn i en fraksjon. Unntaket er plast som ikke er emballasje og drikkevareemballasje. Det finnes flere leverandører av utstyr for innsamling og sortering av plastemballasje (se http://www. plastretur.no/utstyr.html). Vanlig utstyr inkluderer;

- Sekkestativer og konteinere. Slike plasseres der plastemballasjen oppstår. Stativer dekker ulike forbruksvolum, sekker for industri kommer typisk i størrelsesområde 200-1000 liter. Disse er som regel gjennomsiktige og ofte perforerte slik at sortering enkelt kan kontrolleres og at de kan komprimeres.

- Manuelle presser: Lett å plassere, godt egnet for mindre bedrifter men med en stabil produksjon av plastavfall. Ballevekter opp ti $40 \mathrm{~kg}$.

- Emballasjepresser: Plasseres oftest på en sentral oppsamlingsstasjon. Finnes i mange varianter og fasonger med ballevektkapasiteter i størrelsesområde 50 til $250 \mathrm{~kg}$. 


\section{Papp/papir}

Komprimering og bunting av papiravfall er etablert i nærmest alle større forbruksledd og det finnes derfor en rekke produkter for denne anvendelsen (se http://www.eco-web.com/cgi-local/sfc?a=/index/index.html\&b=/ index/category/5.1.html). Slike produkter spesielt tilpasset installasjoner ombord i skip er også tilgjengelig. Mottaksordninger for papiravfall er vel tilrettelagt.

\section{Glass og metaller}

Glass og metaller kan samles samlet. Imidlertid separeres ofte farget glass fra klart glass. Det finnes ulike typer beholdere for oppsamling av disse materialene som oftest er emballasje. Også mer raffinerte løsninger finnes det glass og metall henholdsvis knuses og komprimeres. Mottaksordninger for glass og metall er godt utviklet.

\section{Matavfall}

Våtorganisk avfall er i hovedsak matavfall fra tilberedning og bespisning. Kilde vil altså være bysse/messe. Avfallet kan håndteres ved kompostering, bruk i biogassanlegg eller i forbrenningsanlegg. Fra større husholdninger samles rester fra slik næringsmiddelproduksjon for å bli benyttet i forproduksjon.

Våtorganisk avfall er ofte underlagt særlige restriksjoner også på land. I Norge er det et forbud mot deponering av våtorganisk avfall. Dette går derfor ofte til forbrenningsanlegg. Ved mottaksanlegg vil slikt avfall kunne blandes med annet avfall sortert for forbrenning.

Våtorganisk avfall herunder matrester kan slippes ut innenfor visse rammer men da kun etter oppmaling i kvern og utvannet. Større produsenter av slikt avfall samt for de som ikke kan levere avfallet regelmessig, vil slik oppkverning være et alternativ. Dette må da tilsluttes en oppbevaringstank som kan være samme tank som den som eventuelt benyttes for kloakk. Oppkverningen må være i henhold til kravene som ligger i gjeldende forskrifter.

\section{Elektrisk og elektronisk avfall}

Elektriske og elektroniske, såkalte EE-produkter, er ofte svært sammensatte og kompliserte i avfallsammenheng. De fleste slike produkter inneholder helsefarlige stoffer. Typisk omfatter gruppen produkter som hvitevarer, brunvarer, kontorhjelpemidler (regne-, data-, kopi-, faksmaskiner, m.m.) og er altså ikke typisk forbruksavfall. Slikt avfall skal selvfølgelig leveres på land der det (i hele EU/ EØS område) finnes mottaksordninger for slikt avfall.

Batterier er kanskje et unntak i denne forbindelse. Batterier skal sorteres ut fra øvrig avfallsstrøm og leveres ved egnet mottak. 


\section{Restavfall}

Dette er annet avfall som ikke er egnet til gjenvinning og som ikke er spesialavfall. Eksempler kan være keramikk, støvsugerposer, penner, tusjer, gasbind, tyggegummi, tuber, skitten emballasje, sikringer, m.m. Denne avfallskategorien skal skilles fra annet avfall som kan gjenvinnes og blir oftest deponert. Det er god miljøstrategi å satse på å minimalisere produksjonen av restavfall.

Restavfall skal leveres til mottaksanlegg på land.

Spesialavfall/farlig avfall

I denne kategorien havner alle avfallsgrupper som kan representere alvorlig forurensning og/ eller skade på mennesker og miljø. Eksempler på slikt avfall er impregnerte materialer, maling, whiteprite, batterier, m.fl. Slikt avfall kan i noen sammenhenger behandles for så å benyttes som tilsetningsstoffer i ulike sammenhenger, eksempelvis i sement. Imidlertid skal alt slikt avfall leveres inn på mottakeranlegg. 



\section{Konklusjon}

\subsection{Avfallsmengder}

Det eksisterer ikke verifiserte tallreferanser for hva som genereres av avfall fra skip. Imidlertid er det foretatt flere ulike studier der dette er undersøkt. Nordisk Ministerråd (ref. /9/) ga i 1996 ut en rapport som omtaler avfallsmengder som genereres på færøyske fiskefartøy. Tallene i tabell 1 stammer fra en intervjuundersøkelse som ble utført i dette prosjektet. Den totale mengden husholdningsavfall (matrester og emballasje) er satt til 0,5 kg/person per dag i dette prosjektet.

Tabell 1 Avfallsgenerering på færøyske fiskefartøy (Ref. /9/).

\begin{tabular}{|c|c|c|c|c|c|c|c|}
\hline \multirow[t]{2}{*}{ Skipstype } & \multirow[t]{2}{*}{$\begin{array}{l}\text { Maks. tur- } \\
\text { lengde }\end{array}$} & Matrester & $\begin{array}{l}\text { Emballa- } \\
\text { sje }\end{array}$ & $\begin{array}{l}\text { Nett og } \\
\text { garn }\end{array}$ & Wire & Annet & \multirow{2}{*}{$\begin{array}{l}\text { Olje- } \\
\text { avfall } \\
\text { tonn/år }\end{array}$} \\
\hline & & \multicolumn{5}{|c|}{ Mengde pr. tur } & \\
\hline $\begin{array}{l}\text { Tråler. Enkel, } \\
\text { "grunt" farvann }\end{array}$ & 2 uker & $10-20 \mathrm{~kg}$ & $20-70 \mathrm{~kg}$ & $25 \mathrm{~kg}$ & $200 \mathrm{~m}$ & $\begin{array}{l}\text { Sjakler etc. } \\
15-20 \text { par } \\
\text { hansker }\end{array}$ & $2-4$ \\
\hline $\begin{array}{l}\text { Tråler. Par, } \\
\text { "grunt" farvann }\end{array}$ & 2 uker & $10-20 \mathrm{~kg}$ & $20-70 \mathrm{~kg}$ & $25 \mathrm{~kg}$ & $\begin{array}{l}100- \\
150 \mathrm{~m}\end{array}$ & $\begin{array}{l}\text { Sjakler etc. } \\
\text { 15-20 par } \\
\text { hansker }\end{array}$ & $2-4$ \\
\hline $\begin{array}{l}\text { Tråler. Enkel, } \\
\text { "dypt" farvann }\end{array}$ & 2 uker & $10-20 \mathrm{~kg}$ & $50-70 \mathrm{~kg}$ & $\begin{array}{l}50-400 \\
\mathrm{~kg}\end{array}$ & $\begin{array}{l}300- \\
600 \mathrm{~m}\end{array}$ & $\begin{array}{l}\text { Sjakler etc. } \\
15-20 \text { par } \\
\text { hansker }\end{array}$ & $2-4$ \\
\hline $\begin{array}{l}\text { Tråler. Torsk; } \\
\text { saltet, pakket } \\
\text { og frosset for } \\
\text { salg }\end{array}$ & 4 mnd. & $\begin{array}{l}300-400 \\
\mathrm{~kg}\end{array}$ & $\begin{array}{l}600- \\
1.500 \mathrm{~kg}\end{array}$ & $1.500 \mathrm{~kg}$ & $\begin{array}{l}1.200- \\
1.500 \\
\mathrm{~m}\end{array}$ & $\begin{array}{l}\text { 6-8 tonn } \\
\text { stålballer, } \\
\text { sjakler etc., } \\
100-200 \text { par } \\
\text { hansker }\end{array}$ & $2-4$ \\
\hline Tråler. Reker & 4 mnd. & $\begin{array}{l}200-300 \\
\mathrm{~kg}\end{array}$ & $\begin{array}{l}600- \\
1.000 \mathrm{~kg}\end{array}$ & $1.500 \mathrm{~kg}$ & $\begin{array}{l}1.200- \\
1.500 \\
\mathrm{~m}\end{array}$ & $\begin{array}{l}6-8 \text { tonn } \\
\text { stålballer, } \\
\text { sjakler etc., } \\
\text { Hansker, filler } \\
\text { etc. }\end{array}$ & $2-4$ \\
\hline Langlinefangst & $3 \mathrm{mnd}$ & $10-20 \mathrm{~kg}$ & $\begin{array}{l}600-800 \\
\mathrm{~kg}\end{array}$ & Minimalt & - & $\begin{array}{l}10-20 \text { par } \\
\text { hansker. } \\
\text { Filler etc. }\end{array}$ & $1-2$ \\
\hline Langlinefangst & 2 uker & $10-20 \mathrm{~kg}$ & $20-70 \mathrm{~kg}$ & Minimalt & - & $\begin{array}{l}10-20 \text { par } \\
\text { hansker. } \\
\text { Filler etc. }\end{array}$ & $1-2$ \\
\hline Nett & 2 uker & $10-20 \mathrm{~kg}$ & $20-70 \mathrm{~kg}$ & & - & $\begin{array}{l}\text { Hansker, filler } \\
\text { etc. }\end{array}$ & $1-2$ \\
\hline Linefangst & 2 uker & $10-20 \mathrm{~kg}$ & $20-70 \mathrm{~kg}$ & Minimalt & - & $\begin{array}{l}10-20 \text { par } \\
\text { hansker. } \\
\text { Filler etc. }\end{array}$ & \\
\hline Små båter & 1-2 dager & Minimalt & Minimalt & Minimalt & - & & \\
\hline
\end{tabular}


Norsk sjøfartsadministrasjon (Sjøfartsdirektoratet) utarbeidet i 1994 rapporten "Mottak av avfall fra skip” på oppdrag for Miljøverndepartementet (ref. /10/). I denne inngår en delrapport der blant annet genererte mengder avfall fra fiskefartøy er referert. Nye data er søkt innhentet senere bla. i et prosjekt initiert av de norske havnene Borg Havn, Oslo Havnevesen og Grenland Havnevesen i 2002 (ref. /11/). Imidlertid ble det for fiskefartøy bare gjort mindre justeringer i tallmaterialet. Tallene som gjengis nedenfor er hentet fra den siste oppdateringen (ref. /11/). I den sistnevnte studien ble det foretatt søk i internasjonale søkemotorer og det ble bl.a. innhentet litteratur fra tekniske biblioteker i Norge og Sverige. De tallene som presenteres i tabell 2 kan derfor ses på som relativt representative for fiskeflåten.

Tabell 2 Produserte mengder avfall av de ulike avfallstypene.

\begin{tabular}{lcccc}
\hline Type avfall fra fiske og fangst fartøy & \multicolumn{3}{c}{$\begin{array}{c}\text { Produserte mengder } \\
\text { (Størrelseskategorier, tonnasje i brt) }\end{array}$} \\
\hline & $<300$ & $300-499$ & $500-999$ & $1.000-4.999$ \\
Produsert mengde oljeholdig fast avfall (kg/døgn) & 2 & 3 & 4 & 5 \\
Produsert mengde oljeholdig slam (liter/døgn) & 10 & 20 & 25 & 30 \\
Produsert mengde oljeholdig spillolje (liter/døgn) & 5 & 10 & 15 & 20 \\
Produsert mengde oljeholdig lensevann (liter/døgn) & 10 & 10 & 10 & 10 \\
Produsert mengde kloakk, sort+andel grått (m³/døgn) & 0,3 & 0,4 & 0,5 & 0,7 \\
Produsert mengde søppel ${ }^{1}$ (kg/døgn) & 7,5 & 10 & 12,5 & 17,5 \\
\hline
\end{tabular}

${ }_{1}^{1}$ I produsert mengde søppel inngår kildesorterte fraksjoner. Det finnes ikke tilgjengelige data på hvor stor andel som kildesorteres av de oppgitte tallene.

Tallunderlagene presentert her kan sammen med egne erfaringer benyttes for å beregne produsert avfallsvolum for spesifikke fartøyer under gitte driftsforhold for planlegging av systemer for avfallshåndtering ombord.

\subsection{Håndtering av oljeavfall i fiskefartøyer og mindre båter}

Produksjon av denne avfallskategorien er igjen en funksjon av fartøyenes størrelse og kompleksitet. For de aller minste fartøyene med hyppig havnebesøk, er forskriftsmessig håndtering snarere en rutinemessig utfordring enn en teknologisk.

\subsubsection{Mindre fartøyer på kortere reiser}

Fartøykategorien har relativt sett enkle motortekniske løsninger og genererer svært begrensede volum oljeholdig avfall. Type avfall kan være oljeinfiserte filler, twist, forbruksdeler, etc. samt oljeholdig vann - lensevann. Førstnevnte kategori kan enkelt håndteres ved oppsamling og leve- 
ring til land. Oljeholdig avrenning fra maskiner og mekanisk utrustning er normalt relativt enkelt å samle opp ved kilden. Igjen kan slik avrenning samles på tank, eventuelt på fat eller kanne for videre levering. Mek imidlertid at all slik oppbevaring må samsvare med gjeldende regelverk, jfr. 3.2. Avrenning som blandes i bunnvann - lensevann bør og kan forhindres. Dersom slikt allikevel produseres, bør det samles opp enten i tank eller på fat. Dette kan foretas ved enkle midler som mobile pumper eventuelt ved bruk av absorbsjonsmaterialer.

\subsubsection{Større fartøyer}

Fartøyer med større ytelser og flere kilder til produksjon av oljeholdig avfall, eksempelvis som følge av drivstoffbehandling, vedlikeholdsarbeider, etc., vil normalt være utrustet med mer permanente håndteringssystemer. Ofte begrenses imidlertid dette seg til lensevannsseparator med tilhørende overvåkningsautomasjon samt integrert oppsamlingstank. I noen tilfeller forbrennes også avfallet i et forbrenningsanlegg. Imidlertid vil slik forbrenning ut fra at miljøståsted forsøkes begrenset. Videre er en slik investering neppe forsvarlig for andre enn de aller største fartøyene i denne kategorien som oppholder seg i lange perioder til havs der avfallsopphopning er en reell utfordring. Da altså kombinert med håndtering av avfall generelt. Merk at det er en økning i fokuseringen på utslipp fra slike anlegg, ref. særbestemmelsene som gjelder disse eksempelvis i Østersjøen.

Lensevannsseparatorer krever et vist omfang av vedlikehold og ettersyn. Imidlertid finnes kompakte separatorer for små volum også egnet for ettermontering.

\subsection{Håndtering av kloakk i fiskefartøyer og mindre fartøyer}

Vi har sett at det for kloakk i det aktuelle område finnes to regimer; Østersjøen der slike utslipp er strengt regulert og i Nordsjøen der kravene er noe lempeligere, jfr. 3.3. Slik kan man anta at dersom et fartøy kan operere i Østersjøen over tid med et implementert system for håndtering av kloakk, vil det være tilsvarende i stand til å etterleve kravene i Nordsjøen. For fartøyer som stort sett opererer i Nordsjøen er denne strategien muligens ikke den foretrukne.

\subsubsection{Mindre fartøyer på korte reiser}

Slike fartøyer har ofte liten besetning, 1-3 personer, og oppholder seg alltid nære land med hyppige havneanløp. En del av disse fartøyene kan antas å ikke være utrustet med faste tanker for kloakk, ei heller egnet for 
installasjon av slike. Denne fartøykategorien vil også kunne kjennetegnes ved at den ikke har integrerte løsninger og kun ett sentralt toalett.

Det finnes mindre toaletter som ikke krever integrering i fartøyet der tanken er integrert i selve toalettet for eventuell fjerning og tømming på land. Slike anlegg er ikke beregnet for fast montering, er ofte basert på biologiske prosesser og krever kun tilslutning til strøm (kan fås ned til 12 v.). Det finnes også enklere modeller som ikke krever tilslutninger av noen art.

For fartøyer i denne kategorien der det ikke er hensiktsmessig med tilslutninger til fast oppsamlingstank, vil slike løsninger være hensiktsmessige.

\subsubsection{Større fartøyer}

I denne kategorien kan fartøyet ha en større besetning samt flere kilder. Det er derfor normalt arrangert et sentralt avløpsnett ombord Det er nødvendig å ha en eller annen form for kloakkbehandling for skip som opererer i området med mindre toalettene (eller eventuelt andre kilder til kloakk) skal holdes avstengt i den perioden skipet befinner seg i områder der utslipp ikke er lovlige. Det antas at dette ikke er aktuelt.

Normalt er det relativt enkelt å finne plass til og å installere en fast oppsamlingstank der avløpsstrømmen kan samles på disse litt større fartøyene. Oppsamling på denne måten med levering til land vil være den enkleste og antakeligvis den rimeligste måten å håndtere denne avfallskategorien på. Den vil eliminere utslipp til sjø, og derfor også kunne anbefales ut fra at miljøståsted. Dersom det av årsaker som eksempelvis mannskapets størrelse og reisens varighet, ikke er hensiktsmessig å etablere tanker som kan håndtere det totale volumet produsert, og at man ikke ønsker eller har mulighet til å benytte seg av mulighetene for å tømme volumet i områdene der regelverket gir anledning til dette, er alternativet å behandle kloakken. Igjen finnes det anlegg med lave kapasiteter som er godkjent for fast installasjon og der sluttproduktene kan slippes ut.

I tilfeller der man kombinerer bruk av oppsamlingstank og utslipp i "lovlige” områder, bør det monteres en kvern. Det bør også vurderes installert etterbehandling for desinfisering av kvernet masse før denne slippes over bord.

\subsection{Håndtering av søppel i fiskefartøyer og mindre fartøyer}

De praktiske utfordringene knyttet til håndtering av søppel ombord i fartøyer er ofte knyttet til manglende plass. Andre utfordringer er implementeringen av prosedyrer og rutiner. Det finnes mange eksempler på at uakseptabel avfallshåndtering først og fremst oppstår på grunn av mang- 
lende motivasjon som igjen oftest bunner i fraværelse av kunnskap i relasjon til de effekter forsøpling kan forårsake.

MARPOL 73/78 Annex V kan på mange måter hevdes å være i utakt med metoder og strategier implementert på landsiden i ulike land (også de nordiske). Dette blir tydelig i møtepunktet mottaksordninger for skip. I de internasjonale reglene "blandes" avfall slik at "restavfall" fremstår som en sammenblanding av avfallstyper som det som regel finnes returordninger for. Med basis i dette kan det kanskje være på sin plass å vurdere initiativer for å revidere MARPOL 73/78 Annex V.

Det aller enkleste tiltak for miljøvennlig håndtering av søppel er minimalisering for å redusere generering av slikt søppel. Dette burde være et fokusert tiltak for denne fartøygruppen all den tid plass er et tema. Eksempelvis, svært mye generert søppel er emballasje. Denne er i mange tilfeller overflødig og kan dermed forbli på land. Videre er forbruksreduksjon en faktor som kan bidra til å redusere avfallsproduksjon ombord. Dette kan oppnås ved endrede rutiner, bevisstgjøring av mannskap og i noen tilfeller ved å skifte produkt eller metoder relatert til den aktivitet som genererer avfallet. Eksempler kan være overgang til produkter som har spesielt lang levetid.

\subsubsection{Mindre fartøyer på korte reiser}

En kan forvente at jo mindre et fartøy er, jo mer kritisk er plassaspektet. Imidlertid er også forbruk og behov for proviantering mindre all den tid fartøyets typisk vil besøke havner hyppig. Avfallshåndteringen begynner ved proviantering. Fokusering bør være på det å minimalisere ombordtaking av produkter som genererer avfall. Videre bør det tilrettelegges for avfallsortering. For fartøyer der det finnes flere ulike avfallskilder, bør dette systematiseres ved den enkelte kilde.

Alle fartøyer bør ha en avfallsplan oppslått ombord som visuelt presenterer den praksis som skal følges.

Sortering av avfall krever enkle installasjoner som ulike konteinere/ sekkestativer eller liknende for atskillelse av avfallskategoriene, lagringsfasiliteter for de ulike avfallsgruppene, kverner samt presser i den grad produksjonsvolumet kan forsvare slike.

\subsubsection{Større fartøyer}

For større fartøyer gjelder i utgangspunktet de samme prinsipper som nevnt over. Imidlertid er ofte volum så vel som avfallskompleksiteten ombord i disse fartøyene av en annen art som vil kreve større og mer allsidige kapasiteter.

Større fartøyer skiller seg fra de andre på avfallområde ved at de ikke har samme frekvens mellom havnebesøk, de har en større besetning ombord og videre at de har andre funksjoner ombord som genererer tildels 
uvanlige avfallstyper, eksempelvis fra ombordbasert vedlikehold som genererer malings-, og kjemisk emballasje og rester, utskiftede slitekomponenter, o.s.v. i tillegg til de mer "husholdningsorienterte" avfallsgruppene. Håndtering av volum og kildesortering blir mer kritisk.

Igjen spiller evnen til å definere gode rutiner og prosedyrer samt å effektivt implementere disse inn som vesentlige bidrag til god avfallshåndtering. En avfallsplan er det beste verktøy for å innføre slike rutiner.

Avfall kan også forbrennes i forbrenningsovner. Slike er sjeldent montert i andre enn relativt store fartøyer. Imidlertid kan det være hensiktsmessig med slike anlegg i store fiskefartøyer med lange perioder mellom havneanløp. Merk at det er strenge restriksjoner mot forbrenning av avfall i en del sjøområder. Østersjøen er et slikt område, jf. kap. 3.5. Bruk av forbrenningsanlegg er forurensende og lite forenelig med god avfallshåndtering med mindre den produserte varmen kan omsettes i anvendbar energi. Dette er sjeldent mulig ombord i skip. Argumentet for bruk av slike anlegg bør derfor være at de hindrer utslipp til sjøen.

\subsection{Avfallsplan}

En hovedårsak til mangelfull avfallshåndtering bunner i fravær av en bevisst miljøholdning. Selv i moderne fartøyer med høy grad av avansert teknologi, finner en ofte at dette er tilfelle. I noen industrisegmenter er det arbeidet langsiktig for å forbedre bedriftenes miljøhåndtering og dermed reduserer de miljøbelastningene deres aktiviteter forårsaker. I relasjon til maritime virksomheter, er offshoreindustrien et godt eksempel på at store forbedringspotensialer er mulige. Erfaringene fra disse forbedringsprosessene er ofte relatert til;

- Bevisstgjøring og opplæring - motivasjon

- System - implementering av rutiner og prosesser

- Måling - overvåkning og verifikasjon

Forutsetninger for god avfallshåndtering fra fiskefartøyer og mindre fartøyer hviler også på disse overordnede enkle elementene og kan etableres gjennom utarbeidelse av en avfallsplan. Avfallsplanen kan innlemme både olje, kloakk og søppelhåndtering. Etableringen av en avfallsplan kan starte enklest ved å etablere definerte målsetninger for driften. En slik målsetning vil sette krav til opplæring, implementering av rutiner og prosesser, til måling og overvåkning og først deretter til fartøyets nødvendige utrustninger (arrangementer og teknologier).

Grunnlaget for et slikt verktøy vil inkludere en definisjon av avfallstrømmene ombord inkludert; 
- Hvor - ulikt avfall genereres på ulike steder

- Hvor mye - avfallsproduksjon er en funksjon av størrelse og aktivitet. I tabellen finnes faktorer som kan benyttes for å beregne avfallsvolum.

- Hva slags - skip produserer avfall som papir/ papp/ glass/ plast/ metall/ matavfall og forurenset avfall som mekanisk avfall/ restprodukter o.s.v.

- Hvordan - Behandling, innsamling, håndtering og oppbevaring

Utarbeidelse av en avfallsplan vil synliggjøre behovene for tekniske installasjoner ombord som;

- Kildesorterere (konteinere, sekkestativer, bøtter, etc.)

- Presser for komprimering (av plast, papp/ papir, etc)

- Kverner (for organisk avfall, eventuelt annet avfall)

Gode avfallrutiner kan premieres gjennom fordeler i enkelte havner. Blant annet gir EU-direktivet om mottaksordninger havnene anledning til å gi slike fordeler i tilfeller der avfallstrømmen er håndtert på en slik måte at den er redusert eller forberedt $\mathrm{i}$ henholdt til mottaksanleggets rutiner for avfallsortering.

I følge MARPOL 73/78 skal alle fartøyer med en bruttotonnasje over 400 eller mer eller fartøyer med mer en 15 personer ombord skal ha utarbeidet en avfallsplan for søppel. Fartøyer over 12 meter skal ha en plakat ombord som viser hvilke krav skipet har til håndtering av søppel.

Forbedret dokumentert etterlevelse av gode miljøforpliktelser gir ofte effekter som generell forbedring av arbeidsmiljøet samt kostnadsreduksjoner i relasjon til redusert forbruk samt reduserte avgifter. I følge MARPOL 73/78 skal alle fartøyer med en bruttotonnasje over 400 ha dokumentasjon ombord vedrørende olje og søppel (Oil Recxord Book og Garbage Record Book).

Gjennom regnskapsførsel, miljøregnskap, kan det etableres en oversikt over avfallsproduksjon. Slike regnskap vil etablere en basis for dokumentasjon av den kvalitet den generelle avfallshåndteringen om bord holder. Innføring av rutiner for miljøregnskap kan brukes for verifikasjon i relasjon til mottaksordninger, til motivasjon så vel som til det å identifisere mulige forbedringspotensialer. 



\section{Referanser}

/1/ MARPOL 73/78 Consolidated Edition 2002, IMO.

/2/ 1992 OSPAR Convention, OSPAR.

/3/ Directive 2000/59/EC of the European Parliament and the council of 27. November 2002 on port reception facilities for shipgenerated waste and cargo residues

/4/ Convention on the protection of the marine environment of the Baltic Sea Area (HELCOM), 1992.

/5/ Regler for passasjer og lasteskip m.v. 2004, Sjøfartsdirektoratet, Norge.

/6/ Informasjonsblad nr 14/5.8.2004, Sjöfartsverket, Finland

/7/ Sjøfartsverkets författningssamling (SJÖFS 1985:19)

/8/ Rådsdirektiv 96/61/EF av 24. september 1996 om integrert forebygging og begrensning av forurensning (IPPC direktivet).

/9/ Waste from ships. Nordisk Ministerråd rapport Nord 1996:38. København 1996. Lützen, O. \& Petersen, S. 1996.

/10/ Mottak av avfall fra skip. Sjøfartsdirektoratet, 1994.

/11/ Avfall fra skip, matrise over mengder. Interconsult AS på oppdrag for Borg Havn, Oslo Havnevesen og Grenland Havnevesen. 2002.

/12/ Dansk bekendtgjørelse nr. 629 af 30. juni 2000 om regler for udtømming af kloakspildevand fra lystfartøjer.

/13/ Dansk bekendtgørelse nr 563 af 16. december 1985 om forbud mod udledning af kloakspildevand fra visse kategorier af skibe i Flensborg Fjord. 